C E P R E M A P

CENTRE POUR LA RECHERCHE ECONOMIQUE ET SES APPLICATIONS

Document de travail (Docweb) no 1305

\title{
Development at the border: policies and national integration in Côte d'Ivoire and its neighbors
}

\author{
Denis Cogneau \\ Sandrine Mesplé-Somps \\ Gilles Spielvogel
}




\title{
Development at the border: policies and national integration in Côte d'Ivoire and its neighbors
}

\begin{abstract}
By applying regression discontinuity designs to a set of household surveys from the 1980-90s, we examine whether Côte d'Ivoire's aggregate wealth was translated at the borders of neighboring countries. At the border of Ghana and at the end of the 1980s, large discontinuities are detected for consumption, child stunting, and access to electricity and safe water. Border discontinuities in consumption can be explained by differences in cash crop policies (cocoa and coffee). When these policies converged in the 1990s, the only differences that persisted were those in rural facilities. In the North, cash crop (cotton) income again made a difference for consumption and nutrition (the case of Mali). On the one hand, large differences in welfare can hold at the borders dividing African countries despite their assumed porosity. On the other hand, border discontinuities seem to reflect the impact of reversible public policies rather than intangible institutional traits.
\end{abstract}

Keywords: National Integration, Africa, Borders, Economic Geography, Welfare

JEL Classification: O12, R12, P52

Résumé: En appliquant plusieurs méthodes de régressions par discontinuité à un ensemble d'enquêtes auprès des ménages pour les années 1980 et 1990, nous examinons si la richesse macroéconomique de la Côte d'Ivoire se constatait aux frontières avec les pays voisins. A la frontière du Ghana et à la fin des années 1980, de larges discontinuités sont détectées en matière de consommation, de retard de croissance infantile, et d'accès à l'électricité ou à l'eau. Les discontinuités frontalières de consommation peuvent être expliquées par les différences de politiques concernant les cultures d'exportation (café et cacao). Quand ces politiques ont convergé dans les années 1990, seules les différences d'infrastructures rurales ont persisté. Dans le Nord, le revenu des cultures d'exportation (coton) engendrait aussi une différence en matière de consommation et de nutrition (cas du Mali). D'un côté, de larges différences de bien-être peuvent s'observer aux frontières divisant des pays africains, malgré leur supposée porosité. D'un autre côté, les discontinuités frontalières semblent refléter l'impact de politiques publiques réversibles, plutôt que des caractéristiques institutionnelles intangibles. 


\title{
Development at the border: policies and national integration in Côte d'Ivoire and its neighbors
}

\author{
Denis Cogneau, Sandrine Mesplé-Somps and Gilles Spielvogel*
}

\begin{abstract}
By applying regression discontinuity designs to a set of household surveys from the 1980-90s, we examine whether Côte d'Ivoire's aggregate wealth was translated at the borders of neighboring countries. At the border of Ghana and at the end of the 1980s, large discontinuities are detected for consumption, child stunting, and access to electricity and safe water. Border discontinuities in consumption can be explained by differences in cash crop policies (cocoa and coffee). When these policies converged in the 1990s, the only differences that persisted were those in rural facilities. In the North, cash crop (cotton) income again made a difference for consumption and nutrition (the case of Mali). On the one hand, large differences in welfare can hold at the borders dividing African countries despite their assumed porosity. On the other hand, border discontinuities seem to reflect the impact of reversible public policies rather than intangible institutional traits.
\end{abstract}

Keywords: National Integration, Africa, Borders, Economic Geography, Welfare. JEL classification codes: O12, R12, P52

${ }^{*}$ Denis Cogneau (corresponding author) is senior research fellow and associate professor at Paris School of Economics - IRD; his e-mail address is denis.cogneau@psemail.eu. Sandrine Mesplé-Somps is research fellow at Institut de Recherche pour le Développement (IRD), UMR 225 DIAL, Université Paris Dauphine; her e-mail address is mesple@dial.prd.fr. Gilles Spielvogel is assistant professor at Université Paris 1 Panthéon-Sorbonne, UMR 201 "Développement et Sociétés" (Université Paris 1 - IRD), and DIAL; his e-mail address is gilles.spielvogel@univparis1.fr. The authors thank the National Institutes for Statistics of Côte d'Ivoire, Ghana, Guinea, Mali, and also Burkina Faso, for giving access to their survey data. They thank Charlotte Guénard and Constance Torelli for their participation in the first stage of this study; for historical archives, excellent research assistance from Marie Bourdaud and Angélique Roblin is gratefully acknowledged. They last thank seminar participants at Oxford (CSAE), The Hague (ISS), Clermont-Ferrand (CERDI), Paris (CEPR/EUDN/AFD Conference and PSE), and Washington (World Bank), as well as three anonymous referees. The usual disclaimer applies. 
State consolidation is widely considered to be the most important issue for the development of Africa (e.g., Levy and Sahr Kpundeh 2004), and State failure is often related to difficulties presented by artificial international boundaries (Alesina, Easterly, and Matuszevski 2012). Some authors even consider redrawing international boundaries to be a serious option (e.g., Englebert 2000, 181-189, Herbst 2000, 262-269). For the most part, these boundaries were fixed by European colonial powers and arbitrarily delineated (Barbour 1961 and other references cited in Englebert, Tarango, and Carter 2002), and they have rarely been modified since then (Brownlie 1979). Given the weakness of African States, the reach of national policies in peripheral border areas has been extensively questioned. Furthermore, African borders are often assumed to be permeable, particularly to informal trade and migration flows that may level international differences. Are African boundaries still abstract lines drawn on a map, so that divided areas remain alike and no difference in welfare is observed when crossing the border? Or have they become real,strong discontinuities that reveal an ongoing process of national integration? These are the questions that we address in this paper.

The literature on Africa's development presents a variety of arguments regarding the role played by boundaries between States.

A first group of contributions supports the idea of boundaries' weaknesses and porosity. This idea is implicitly present in papers stressing the role of geography (e.g., Bloom and Sachs 1998). Other papers more directly build upon the underdevelopment of state institutions. According to Herbst (2000, 171), the guaranty from the United Nations discourages African States from investing in territorial control; whoever holds the capital city holds the country, "the broadcast of power radiating out [from the political core] with decreasing authority". These "territory- 
states", as opposed to nation-states, are in keeping with pre-colonial political institutions in a context of low population density. Within former French West Africa, Huillery (2009) relates part of the present-day spatial inequality within countries to decentralized policies in early colonial times. Other papers propose the role of ethnicity. Common languages and cultures contribute to informal crossborder flows of goods, money, and people across "permeable boundaries" (Griffiths 1996). Studying the markets for millet and cowpea at the Niger-Nigeria border, Aker et al. (2010, 26) argue that "ethnic borders map the geography of trade more effectively than international borders do". According to Michalopoulos and Papaionnou (2012, 2013), in Africa, precolonial political institutions are a more powerful determinant of development than national institutions. At the border between Côte d'Ivoire and Ghana, Bubb (2012) finds no difference in the management of property rights on land. Finally, Easterly and Levine (1998) find that countries' growth is strongly influenced by the countries' neighbors.

A second strand of the literature stresses the salience of national idiosyncrasies and a centripetal effect of boundaries. As noted by Robinson (2002) in his review of Herbst, the boundaries of Latin American countries, which became independent at the beginning of the 19th century and are now considered well-established nation-states, also exhibit some degree of arbitrariness. Bach (2007) presents a similar argument. Furthermore, ethnic salience is not fate. Posner (2004) observes that among two ethnic groups at the border between Malawi and Zambia, ethnic identification varies when crossing the border. Miguel (2004) suggests that the promotion of national identity by the Tanzanian leader Julius Nyerere succeeded in canceling out the negative impact of within-village ethnic heterogeneity on public goods provision observed in neighboring villages of Kenya. Furthermore, many 
authors emphasize that differences in prices, taxes, and market demand create economic opportunities that are exploited every day by agents living in border areas (Bach 1997, Nugent 2002). Although initially arbitrarily delineated, boundaries have become a reality, if only for economic life. Comparing communities on both sides of the Côte d'Ivoire-Ghana border, MacLean (2010) argues that patterns of social insurance differ and were shaped by colonial and post-colonial state action. Asiwaju (1976) and Miles (1994) develop similar arguments about the contrast between British and French colonial imprints at the Benin-Nigeria and the NigerNigeria borders, respectively. Finally, at the macroeconomic level, the inequality of income between African countries is larger than usually thought. According to Schultz (1998), the log variance of GDP per capita in PPP reached 0.415 in 1989 in Africa (including North Africa), which is by far the highest level of all regions of the world. Furthermore, this number is twice as high as it was in 1960 (0.213). Of course, income divergence between African countries may only reflect the divergence of their centers rather than their border areas. However, this possibility would be difficult to reconcile with a strong influence of neighbors on growth. ${ }^{1}$

Drawing from a large set of household surveys covering the 1986-98 period, we estimate regression discontinuity designs at the borders of Côte d'Ivoire with Ghana, Mali, and Guinea, focusing on four welfare outcomes: consumption and children's nutritional status (height-for-age), on the one hand, and the connection to electricity and access to safe water, on the other hand. When discussing the main results, we also examine household cash crop output and incomes.

\footnotetext{
${ }^{1}$ The insulating power of boundaries is not necessarily for the good. Englebert, Tarango, and Carter (2002) talk of political "dismemberment" and "suffocation". Further, the "balkanization" of Africa is often believed to prevent the exploitation of returns to scale, despite efforts of regional trade integration. However, the impact of full political integration is different from a simple size merger (Spolaore and Wacziarg 2005).
} 
Côte d'Ivoire is an interesting case study; at least in the 1980s and 1990s, it was much wealthier than all of its neighbors. The evidence provided by border discontinuity estimates is more mixed.

We document the hazards that commanded the alignment of boundaries during the colonial era and show that predetermined geographical and historical conditions should not account for border discontinuities in welfare.

At the eastern border with Ghana and at the end of the 1980s, large border discontinuities existed for the four outcomes. However, because the 1990s brought crisis to Côte d'Ivoire and recovery in Ghana, border differences in income were very much attenuated, and the discontinuity in nutrition vanished. Discontinuities in access to electricity and water were preserved. In contrast, at the northern border with poorer and landlocked Mali and in the mid-1990s, Côte d'Ivoire performed better in terms of income and nutrition, but not in access to utilities. The border with Guinea provides a case in which the Côte d'Ivoire advantage is canceled out along all dimensions. A more detailed analysis shows that income derived from cash crops almost fully accounts for the large differences in consumption at the borders of Ghana and Mali. Because the cocoa frontier had not yet reached the extreme west in the 1990s, the same factor explains why no discontinuity is found at the border with Guinea.

Border discontinuities reveal the role of two types of national policies: policies affecting cash crop production and public investment in utilities. Although differences in such policies have had large and visible impacts at borders, they are not irreversible, and some of them were changed in the years that followed. We conclude that large border discontinuities can be observed between African countries in the short run, but they do not necessarily reflect divergent trajectories linked 
to long-lasting institutional features.

Section I presents the analytical methodology and explains the econometrics. Section II documents the historical and geographical backgrounds of borders. Section III presents survey data and border discontinuities in development outcomes, first for the eastern border with Ghana and then for the northern borders. Section IV provides further discussion of the cash crop channel and national policies. Section V concludes.

\section{Analytical methodology}

Here, we discuss the conditions under which the borders we study can be considered historical "natural experiments". Consider a person born somewhere in the area now named Côte d'Ivoire. What would her welfare be if Côte d'Ivoire had been colonized by the British instead of the French, like Ghana, and then exposed to post-colonial Ghanian policies and institutions? This question is difficult to answer for at least three reasons: (i) the British could have established different institutions to rule Côte d'Ivoire; (ii) Ghana and Côte d'Ivoire combined would not be the same, if only because of market size and general equilibrium considerations; and (iii) even if Ghana's institutions had remained the same, we have no idea how Côte d'Ivoire's initial characteristics would interact with them. Now, take a person born in Côte d'Ivoire at the border of Ghana and imagine that the border was some kilometers farther. Including this person in Ghana would have a marginal and insignificant impact on Ghana's institutions and economy. Furthermore, it is very probable that this close neighbor of actual Ghanaian people would share the same geographical constraints and the same precolonial initial conditions. 
Let $Y$ be some outcome variable (income, connection to electricity, etc.) observed over a sample of people living in two countries at the same date. Let $C=0,1$ be the dummy variable indicating the country of residence. Let $Y_{i}(0)$ be the outcome if and when the individual (or household) $i$ lives in the country $C=0$ and $Y_{i}(1)$ in the country $C=1$. The observed outcome reads thus:

$$
Y_{i}=\left(1-C_{i}\right) . Y_{i}(0)+C_{i} \cdot Y_{i}(1)
$$

The identification of the average treatment effect, $E[Y(1)-Y(0)]$, is probably out of reach, but a regression discontinuity $(\mathrm{RD})$ design based on distance to the border should correctly approach its local version (LATE) in the vicinity of the border.

\section{Required assumptions for a border RD}

Let $D_{i}$ stand for the distance to the border of the locality of residence, positively signed for country 1 and negatively signed for country 0 , so that $C_{i}=1\left\{D_{i} \geq 0\right\}$. Under the assumption that $E[Y(0) \mid D=d]$ and $E[Y(1) \mid D=d]$ are continuous in $d, \lim _{d \rightarrow 0^{+}} E[Y \mid D=d]-\lim _{d \rightarrow 0^{-}} E[Y \mid D=d]$ provides an estimation of the average treatment effect at the border (Hahn, Todd, Van Der Klauw 2001). It is the so-called "sharp" RD estimator. As Lee (2008) argues in another context, this continuity assumption is difficult to assess and impossible to test. Lee's reformulation elucidates the conditions under which an $\mathrm{RD}$ replicates a random assignment around the threshold $D=0$. Assume $Y$ is generated by a partially unobservable random variable $W: Y(0)=y_{0}(W)$ and $Y(1)=y_{1}(W)$. $W$ represents the "type" of individuals, households, or localities with respect to $Y$. Finally, let $F(d \mid w)$ 
stand for the cdf of $D$ conditional on $W$. Lee's conditions are as follows (Lee 2008, 679):

(i) $F(d \mid w)$ is such that $0<F(0 \mid w)<1$

(ii) $F(d \mid w)$ is continuously differentiable in $d$ at $d=0$, for each $w$ in the support of $W$

Condition (i) of overlap requires that $D$ can be written $D=Z(W)+e$, where $Z$ is the predictable component of $D$ and $e$ is an exogenous random chance component, so that the probability of receiving treatment is somewhere between 0 and 1 for each type. Condition (ii) of unconfoundedness implies that conditional density $f(d \mid w)$ is continuous in $d$ at $d=0$. In our case, this implies that within each type $w$ and very near to the border, the probability of being allocated to one side or another is the same. However, in the overall population, $D$ can be arbitrarily correlated with $Y(0)$ or $Y(1)$; $Y$ may also be directly generated by $D$ in addition to $W$ (Lee 2008, 680). Under these conditions, the RD estimate is a weighted average of the difference $y_{1}(w)-y_{0}(w)$ for each type $w$, with weights equal to the probability of being close to the border: $f(0 \mid w) / f(0)$.

At the locality level, Lee's conditions require that border localities are not sorted by "types" $w$ between the two countries. This randomness of distance to the border should stem from the historical hazards of boundary alignment during the colonial period, which we document below.

At the individual level, the same conditions require that people do not "manipulate" their distance to the border through migration. This is typically an issue for embodied outcomes such as human capital. International migration based on $y_{1}(w)-y_{0}(w)$, or more generally on $w$, is obviously the worst case. However, even 
internal migration flows based on $w$ are a source of bias because the center of one country may be more attractive than the other for a given type $w$ (for instance, a larger number of good schools or good jobs in Abidjan than in Accra).

Because we do not observe types $w$, we cannot test directly for the validity of these assumptions, namely that the distribution of the "types" $w$ is the same on both sides near the border.

However, we can check the continuity of the density $f(d)$ at $d=0$ to detect sorting at the border (i.e., selective village settlement or migration). Additionally, we can test for discontinuities in the distribution of observable variables that can be considered predetermined, such as geographical variables. This is done in section II.

We address internal migration to border areas by restricting our estimates to the sub-sample of household heads born in border districts (Ghana border) or belonging to the Mande-Voltaic ethnic group (northern borders). For international migration, we additionally exclude heads who are not nationals of the side where they live (e.g., Malians who live on the Côte d'Ivoire side of the border area). This is a very conservative procedure because migrations out of border areas to capital cities or to wealthier areas are disregarded. In previous versions of this work, we showed that doing so provides a lower bound for the Côte d'Ivoire advantage because the impact of internal migrations within this country dominates the impact of other migration flows. 


\section{Implementation of border RD estimates}

To implement the border RD estimator just described, the regression functions $E[Y(1) \mid D=d, C=1]$ and $E[Y(0) \mid D=d, C=0]$ must be estimated around the border point $D=0$. Sample sizes preclude using more flexible but slowly converging non-parametric estimators. As is often done in the literature, we therefore introduce parametric assumptions. Furthermore, we conservatively collapse all data at the level of surveys' primary sample units (PSUs) and analyze the PSUs' averages. All estimates use the PSUs' sample weights. ${ }^{2}$ We consider three kinds of estimators.

First, we implement locally linear regressions for narrow enough bandwidths $h$ equal to either 50 or $75 \mathrm{~km}$ :

$$
Y=\gamma(h) \cdot C+\alpha_{0}(h)+\beta_{0}(h) \cdot(1-C) \cdot D+\beta_{1}(h) \cdot C \cdot D+\varepsilon
$$

for $-h \leq D \leq h$, and with $h=50,75$. We call this estimator "border RD".

Second and alternatively, we disregard distance to the border $D$ and estimate a polynomial of degree three in latitude and longitude, like Dell (2010):

$$
Y=\delta(h) \cdot C+P(a(h), L A T, L O N)+\zeta
$$

for $-h \leq D \leq h$, again $h=50,75$, and $a(h) \in \mathbb{R}^{9}$. In this case, we assume that this cubic polynomial in latitude and longitude adequately describes the space of "types" $w$ on both sides of the border. ${ }^{3}$ We call this estimator "polynomial RD".

\footnotetext{
${ }^{2}$ To correct for differences in sampling rates between countries, PSUs' sample weights are re-scaled by countries' total population. Of course, those "population weights" are still treated as probabilistic weights for statistical inference.

${ }^{3} P(a, L A T, L O N)=a_{10} L A T+a_{01} L O N+a_{20} L A T^{2}+a_{02} L O N^{2}+a_{11} L A T . L O N+a_{30} L A T^{3}+$
} 
Third and last, we implement a matching estimator on geographical distance that includes controls for distance to the border (i.e., combines matching and RD features). We call this "matching RD". This is inspired by Gibbons, Machin, and Silva (2009). We match each PSU $j$ with its nearest neighbor $\nu(j)$ on the other side of the border. We sign the differences in outcome between matches $\left(\Delta Y_{j}=Y_{j}-Y_{\nu(j)}\right)$ so that positive differences designate a Côte d'Ivoire $(C=1)$ advantage. We then regress the signed difference on the distance to the border of the matched PSU, again with locally linear regressions on each side:

$$
\Delta Y=\theta(h)+\beta_{0}^{\prime}(h) \cdot(1-C) \cdot D+\beta_{1}^{\prime}(h) \cdot C \cdot D+\eta
$$

for $-h \leq D \leq h$ and $h=50,75$. Because different localities $j$ in the same country can share the same nearest neighbor $\nu$, we cluster the standard error $\eta$ by $\nu .{ }^{4}$

In the case of the Mali border, where sample sizes do not allow the implementation of the narrowest $50 \mathrm{~km}$ bandwidth, we instead produce $100 \mathrm{~km}$ bandwidth estimates, where, for "border RD" and "matching RD", we add the square of the distance to the border $\left(D^{2}\right.$, interacted with the $C$ dummy as well).

When examining border discontinuities in development outcomes, we add to all specifications a few geographical controls: we use latitude in the case of the Ghana and Guinea borders and longitude in the case of Mali as well as rainfalls, elevation, and distance to the nearest river. In specification (4), we use the difference between matched neighbors for all of these variables (again signed properly). $\overline{a_{03} L O N^{3}+a_{21} L A T^{2} \cdot L O N+a_{12} L A T} . L O N^{2}$

${ }^{4}$ We also attempted a richer model that included the distance to the border of the matches. The estimates were not significantly different from those of the simpler model, although they were sometimes more imprecise. For the $75 \mathrm{~km}$ bandwidth sample of PSUs, the average distance to the border of the nearest neighbor matches varies between 10 and $13 \mathrm{~km}$. 
In the remainder of this paper, we use the acronym "BD" for border discontinuity.

\section{Historical and geographical background}

We first document the historical alignment of the boundaries around Côte d'Ivoire, drawing from the literature as well as from dedicated research in French colonial archives. This approach allows us to address the overlap assumption (random chance component of borders, see above). ${ }^{5}$ Then, we document the geographical features of the boundaries. A few statistical tests assess the unconfoundedness assumption.

\section{History}

The drawing of boundaries in West Africa was arbitrary, to a large extent (e.g., Hargreaves 1985), and very often divided pre-colonial political entities. Even structured kingdoms drew no maps, and they could be composed of groups that spoke different languages, such as the Gyaman kingdom across the border from Ghana (Terray 1982). Ethnic groups are historical objects that were at least influenced, if not constructed, by pre-colonial, colonial, and post-colonial politics (e.g., Amselle and M'Bokolo 1985, Posner 2005). Furthermore, the classification of ethnic names is not independent from the national political economy. Despite these caveats, we verified in available mappings (Murdock 1959; language maps from Ethnologue: Lewis 2009) that the international boundaries we consider are not confounded by hard delimitations between ethno-linguistic areas.

\footnotetext{
${ }^{5}$ For the sake of space, we only present a brief summary of our historical investigation. A supplemental appendix on history is available at http://wber.oxfordjournals.org/.
} 
During the 19th century, the largest part of the border between Côte d'Ivoire and Ghana was under the domination of the Ashanti Empire, whose capital city, Kumasi, was located in central present-day Ghana. In localities that lie no further than $75 \mathrm{~km}$ from this border and in the years 1986-8, surveys indicate that more than $50 \%$ of household heads belonged to the Akan ethno-linguistic grouping, which includes the Ashanti people: $56 \%$ on the Côte d'Ivoire side and $59 \%$ on the Ghana side. At the end of the 19th century, the French and British began to extend their domination from trade posts located on the coast toward the North by signing protectorate treaties with local kingdoms. Negotiations between the two colonial powers finally resulted in partitions of pre-colonial political entities in the middle part of the border (Gyaman, Indenie, Sefwi). In its southern part (Sanwi), a rebellion unsuccessfully challenged the border alignment after independence. The layout of the last demarcation on the field, with teak trees, beacons, and pillars, was achieved in 1988 .

The two other borders of Côte d'Ivoire that we examine are less clearly demarcated on the field (Brownlie 1979). In surveys, the great majority of household heads belong to the Mande-Voltaic ethno-linguistic grouping. In particular, the boundary between Côte d'Ivoire and Mali lies across the Senoufo (Gur/Voltaic) area in its eastern part and the Malinke (Mande) area in its western part. The hazards of French conquest and of the wars against the Almami Samori Toure at the end of the 19th century reflected the boundaries' alignment within the French Empire and resulted in partitions of some former political entities (Kenedougou and Kong kingdoms). These borders were only stabilized after World War I.

We also use French data for the colonial period (Huillery 2009) and explore differences in initial conditions between the border areas lying inside the French 
empire (Mali and Guinea). Pairwise comparisons do not reveal significant differences in terms of European settlement, tax revenue, or public expenditures (see table S1.1 in the supplemental appendix). One exception is perhaps that the Mali border districts exhibited higher population density. As we shall see in the following subsection, this feature has been reversed since then.

\section{Geography}

First, we check the continuity of the density of the distance to the border. The usual RD tests for sorting (Lee 2008, McCrary 2008) must be adapted to our context. We cannot only count the number of primary sample units because the sample stratification and sample rates differ between country surveys. For each bandwidth and each border size, we compute standardized "relative PSU weights" by dividing the original weights by their mean. The test then detects whether relatively more people are found closer to the border on one side compared to the other. The first row in Table 1 shows the result of this test in the case of the Ghana border. No border discontinuity is detected; one minor exception is the polynomial method at a bandwidth of $50 \mathrm{~km}$. The same is found for Mali and Guinea at $75 \mathrm{~km}$ distance (see appendix table A.1), which will be our preferred bandwidth everywhere. 
Figure 1: Map of border areas with PSUs and regional cities

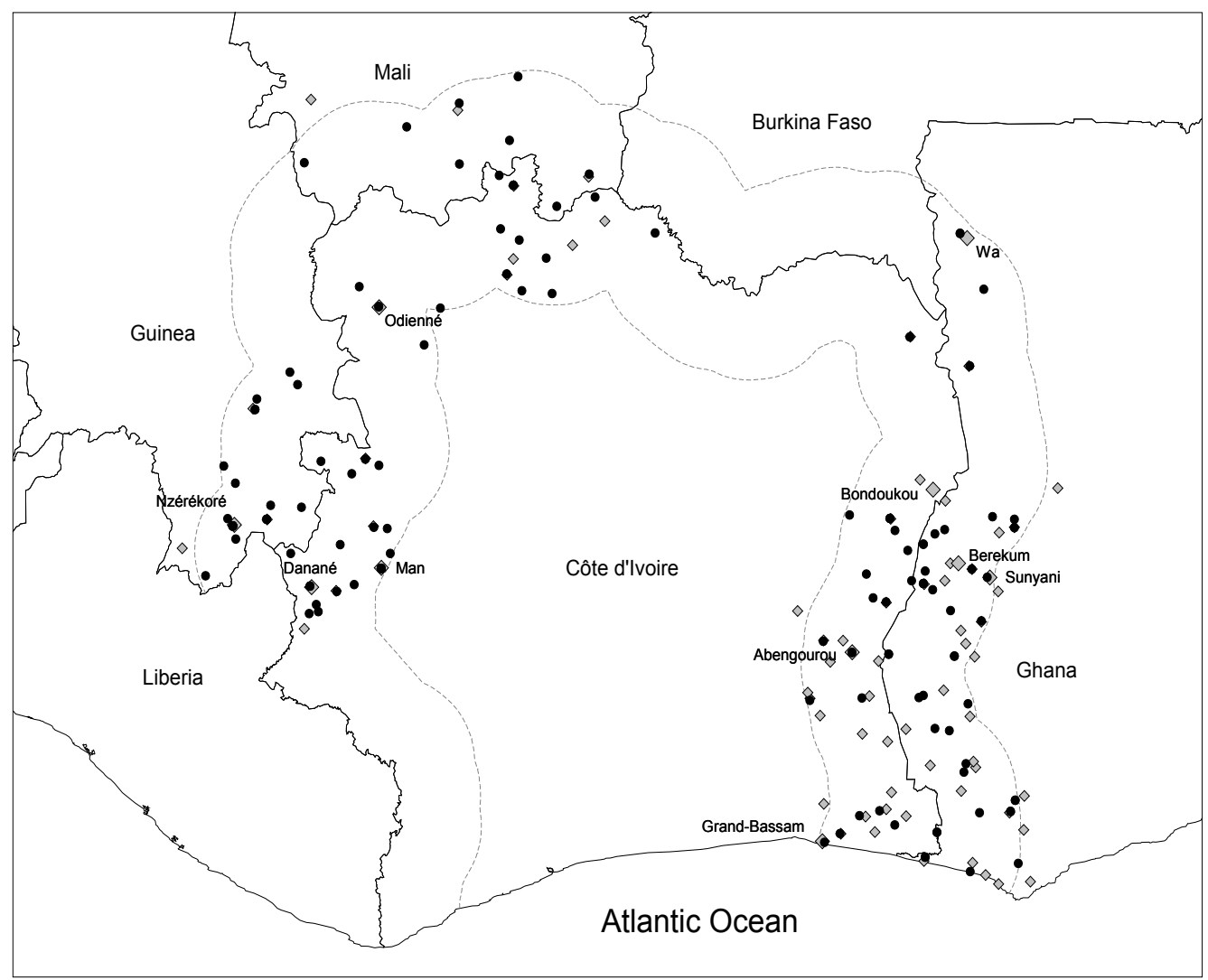

Note: Black dots indicate the location of primary sample units (PSUs) for the 1986-8 surveys at the Côte

d'Ivoire-Ghana border and for the 1992-4 surveys at the borders with Mali and Guinea. Grey diamonds indicate the location of regional cities (5,000 inhabitants or more) as of 1990; city names are reported only for cities over 30,000 inhabitants. The dashed line delineates the $75 \mathrm{~km}$ bandwidth around the boundaries.

We then characterize the PSUs of household surveys by five geographical variables: rainfall, elevation, distance to the nearest river, population density, distance to the closest regional city, and distance to the capital city (for more details on variable sources and construction, see supplemental appendix S2). The geographical locations of cities with 5,000 inhabitants or more in the years 1960 and 1990 
are drawn from the Africapolis database. ${ }^{6}$ Even natural geography should not be too quickly considered to be predetermined before the drawing of the boundaries. Deforestation can influence rainfall, and even elevation or watercourses can, to some extent, be reshaped by human activity. Further, geographical discontinuities are measured on a sample of localities whose settlement is not random. However, we expect to find no or few discontinuities in rainfalls, altitude, and hydrography, and we regard this result as corroborating the quasi-randomness of the boundaries' alignment. Conversely, constructed geography, such as population density or city distribution, is far from being independent from boundaries. Nevertheless, we want to explore the extent to which discontinuities in welfare should be linked to discontinuities in urban structures. Finally, due to differences in countries' shape and spatial organization, distance to the capital or main city does not vary smoothly at borders. Any border effect includes a change in the capital city and a shift in the distance to it.

The major part of the border of Côte d'Ivoire with Ghana does not follow a natural line, except the lagoon in the extreme South and the Black Volta river in the extreme North. Given our sample distribution, these two parts contribute little to our estimates, and withdrawing them changes nothing. The border with Ghana does not exhibit any discontinuity in our geographical variables, except distance to the capital city: the Ghana border is closer to Abidjan than it is to Accra by 130 to $150 \mathrm{~km}$ (table 1$)$.

\footnotetext{
${ }^{6}$ This database from geographers (SEDET, CNRS and University Paris-7) is probably the most complete to date. We are grateful to Eric Denis for making it available to us. We prefer not to use the urban/rural status of localities as recorded in surveys because (i) countries do not use the same definition for urban areas, and (ii) this precludes distinguishing peri-urban rural areas from more isolated ones.
} 
The same is found for Mali in the $75 \mathrm{~km}$ bandwidth, except that here the border is farther away from Abidjan than from Bamako by approximately $300 \mathrm{~km}$ (top panel of table A.1). On both sides, as seen in figure 1, very few PSUs are found on the western part, which is underpopulated, probably due to the prevalence of parasitic diseases. Again, withdrawing the two or three most western PSUs (above longitude $7^{\circ} \mathrm{W}$ ) is innocuous. When enlarging the bandwidth to $100 \mathrm{~km}$, additional Ivorian PSUs are found to lie relatively farther away from the border in the South. Their inclusion produces a significant "matching RD" discontinuity in rainfall. This leads us to prefer the narrower $75 \mathrm{~km}$ bandwidth.

Table 1: Geographical variables at the border of Côte d'Ivoire with Ghana

\begin{tabular}{|c|c|c|c|c|c|c|}
\hline \multirow[b]{2}{*}{ Bandwidth in $\mathrm{km}$ : } & \multicolumn{2}{|c|}{ Border RD } & \multicolumn{2}{|c|}{ Polynomial RD } & \multicolumn{2}{|c|}{ "Matching RD } \\
\hline & 50 & 75 & 50 & 75 & 50 & 75 \\
\hline \multirow[t]{2}{*}{ Relative PSU weights $^{a}$} & -0.25 & -0.14 & $-0.35^{*}$ & -0.19 & -0.06 & -0.13 \\
\hline & $(0.20)$ & $(0.18)$ & $(0.18)$ & $(0.18)$ & $(0.41)$ & $(0.30)$ \\
\hline Rainfall (mm per day $)^{b}$ & +.028 & +.012 & -.008 & -.011 & -.011 & -.005 \\
\hline \multirow[t]{2}{*}{ Elevation (meters) } & $\begin{array}{l}.0201 \\
+25\end{array}$ & $\begin{array}{l}.021) \\
+25\end{array}$ & $\begin{array}{l}.000) \\
+20\end{array}$ & $\begin{array}{l}.0019 \\
+19\end{array}$ & $\begin{array}{l}.000) \\
+0\end{array}$ & $\begin{array}{c}.000 \\
-1\end{array}$ \\
\hline & (37) & $(25)$ & $(32)$ & (23) & $(22)$ & (16) \\
\hline \multirow[t]{2}{*}{ Dist. nearest river $(\mathrm{km})$} & -1.5 & -1.1 & +4.0 & +3.5 & +0.1 & -1.5 \\
\hline & $(8.9)$ & $(6.6)$ & (6.4) & (5.3) & $(5.4)$ & $(4.0)$ \\
\hline \multirow[t]{2}{*}{ Dist. city $5,000+1960(\mathrm{~km})$} & +14.1 & -3.7 & -3.2 & -8.3 & +6.9 & +0.2 \\
\hline & $(16.0)$ & $(15.7)$ & $(20.0)$ & $(16.9)$ & $(30.3)$ & $(23.4)$ \\
\hline \multirow[t]{2}{*}{ Dist. city $5,000+1990(\mathrm{~km})$} & -6.3 & -13.5 & -18.1 & -21.3 & -5.9 & -10.4 \\
\hline & $(11.0)$ & $(8.8)$ & $(11.9)$ & $(12.8)$ & $(15.1)$ & $(11.9)$ \\
\hline \multirow[t]{2}{*}{ Pop. density 1990 (inh./ $\left./ \mathrm{km}^{2}\right)$} & -5.9 & -17.5 & +3.7 & -17.7 & -6.3 & -4.4 \\
\hline & $(11.2)$ & $(26.3)$ & $(10.3)$ & $(12.9)$ & $(7.6)$ & $(9.7)$ \\
\hline \multirow[t]{2}{*}{ Dist. capital city (km) } & $-131^{* * *}$ & $-136 * * *$ & $-150 * * *$ & $-153^{* * *}$ & $-137 * * *$ & $-140 * * *$ \\
\hline & (14) & (14) & (13) & (13) & $(22)$ & (19) \\
\hline
\end{tabular}

Source: Authors' analysis based on data described in the text.

Coverage: PSUs in the bandwidth window (50 or $75 \mathrm{~km}$ from the corresponding border).

Notes: See equations (2), (3), and (4) for each estimator. For "Border RD" and "Matching RD", the only control variable is latitude.

a: Probabilistic weights with means standardized to one on each side of the border. Non-weighted estimates.

b: Average over the 1984-2001 period.

Positive numbers indicate differences in favor of Côte d'Ivoire. Standard errors in parentheses.

${ }^{* * *}: p<.01 ; * *: p<.05 ; *: p<.10$

In both the Ghana and Mali cases, the Côte d'Ivoire side is slightly more urbanized. Although not significantly so, Ivorian localities lie closer to the regional 
cities of 1990 by 6 to 21 (Ghana border, table 1) or 7 to $13 \mathrm{~km}$ (Mali border, table A.1), depending on the estimates. However, the BDs are reversed when considering the distance to locations that were already cities in 1960, especially at the Mali border. We link this post-independence urbanization process to the rapid economic growth of Côte d'Ivoire and, more locally, to the expansion of either cocoa (Ghana) or cotton (Mali) production. Lower population density on the Mali side could also be linked to the persistence of "river blindness" (onchocerciasis), which was previously fought and eradicated in Côte d'Ivoire.

Finally, in the case of Guinea, half of the alignment is based on rivers; "parts of watercourses, from map evidence, are tortuous, indecisive and many-armed" (Brownlie 1979, 374). The southern part of this border is also rather mountainous. A few discontinuities are found for elevation and distance to rivers that could put the BD estimates in question. We give it less weight in our comments and conclusions. However, no discontinuity in welfare will be identified at this border.

\section{Data and main results}

After a short presentation of the survey data, we analyze border discontinuities in development outcome variables.

\section{Survey data on development outcomes}

We gather a database composed of 15 multi-topic household surveys: seven for Côte d'Ivoire, six for Ghana, one for Mali, and one for Guinea. These surveys were implemented between 1986 and 1998 (table A.2). We mainly use "income surveys", which correspond to the frame of Living Standard Measurement Surveys (LSMS), 
as designed by the World Bank in the 1980s. These surveys allow the measurement of consumption and income sources, and we code the geographical location of PSUs with precision using the locality name. We complement these income surveys with Demographic and Health Surveys (DHS), which do not measure consumption but record anthropometric data as well as housing conditions. All sample designs are two-stage and regionally stratified, and each PSU contains between 12 and 25 households.

We choose to analyze four different welfare outcomes: consumption per capita, children's height-for-age, access to electricity, and access to a man-made source of water. Despite the multi-topical nature of these surveys, very few other welfare outcomes are usable for comparison.

First, we construct a household expenditure variable that includes all current expenditures, such as food, clothing, transportation, housing, and imputed rents, and expenditures for education. We only exclude overly infrequent or badly measured expenditures such as those in health, durable goods, and transfers. Except for Mali, we also compute the value of the consumption of own food production, which we add to household expenditures to obtain a total consumption variable. We use monthly data on the national consumer price index and express individual household consumption at 1988 or 1993 prices. Comparisons of household consumption levels are made in US dollars at 1988 or 1993 exchange rates and prices. ${ }^{7}$ We consider one important component of agricultural income, household production of the three main cash crops produced in the region: cocoa, coffee and cotton. We retain the value of output sold, either as directly reported by the households (Ghana and Guinea borders) or as physical quantities priced at the official

\footnotetext{
${ }^{7}$ For more details on the construction of variables, see section $\mathrm{S} 2$ of the supplemental appendix.
} 
and uniform producer price (Mali border; the Malian survey only records physical cotton output). We also extract data on wage incomes earned by household members.

Second, height stature is available for children from six months to four years (59 months) of age, and only for 6-35 months in some DHS. We construct heightfor-age Z-scores using the World Health Organization standards (WHO 2006) and code children as stunted when the Z-score is below -2 .

Third, from both types of surveys, we construct a dummy variable indicating whether the household uses electricity as the main source of light in the house. The surveys do not distinguish between being connected to a network or using a private generator.

Fourth and last, a second dummy variable codes whether the household has access to a man-made source of water (i.e., any source of water other than rivers, lakes, pools, or rainfalls) (Ghana border only).

\section{The border with Ghana}

For the 1986-8 period, both national accounts and income surveys provide similar figures for consumption per capita in the two countries. Côte d'Ivoire appears wealthier than Ghana by a large 344-375 USD gap at 1988 prices and exchange rates (table 2, upper top panel). Cocoa and coffee income figures computed from FAO data and from surveys are also quite consistent. When restricting the comparison of survey means to the sub-sample of administrative districts lying along the boundary, the gap in consumption is slightly reduced but remains as large as 282 USD, whereas the cash crop income difference widens to +174 USD because 
the Ivorian side is a very important cocoa and coffee production area. The year 1993 marked the climax of an enormous macroeconomic crisis in Côte d'Ivoire, triggered by the collapse of international prices for cocoa and coffee in 1987 and the halving of administered producer prices in 1990. In contrast, Ghana began a progressive recovery from two decades of economic and political turmoil. In the case of Côte d'Ivoire, survey figures exhibit a greater fall than national accounts (table 2, lower top panel). This may be due to under-reporting biases in the less detailed 1992-3 survey and/or to the inaccuracy of national accounts, which compute private consumption as a residual. Côte d'Ivoire remains the wealthiest country, even in border districts, where a significant gap of +76 USD per capita is observed. Cash crops' income differences remain statistically significant but are ten-fold lower (+17 USD). Unfortunately, the absence of geographical coordinates in the 1992 Ghanaian income survey prevents us from using these consumption and income figures for the computation of BDs.

The BD estimates are reported in table 3, again for the two periods of 1986-8 (top panel) and 1993 (bottom panel), and for the set of four welfare indicators. Column (1) reports the difference between survey means at the national level, and columns $(2 \mathrm{a})$ to $(4 \mathrm{~b})$, respectively, report the BD obtained when implementing our three estimation methods with two bandwidths, 50 or $75 \mathrm{~km}$, as in table 1 . In 1986-8, we are able to restrict the estimates to the sub-sample of heads born in border administrative districts and in the country of residence. This allows us to test whether discontinuities hold among people sharing the same region of origin or "ethnicity" because part of the above-mentioned literature is concerned with this dimension, especially the fact that shared preferences or intense trade flows may equalize welfare among ethnic groups. We favor the district of birth variable 
Table 2: National accounts and Survey means: Côte d'Ivoire, Ghana and Mali

\begin{tabular}{|c|c|c|c|}
\hline & Côte d'Ivoire & Ghana & Diff. $^{e}$ \\
\hline \multicolumn{4}{|l|}{$1986-8$} \\
\hline Official: Consumption ${ }^{a}$ per cap. & 651 & 308 & +344 \\
\hline Survey: Consumption ${ }^{b}$ per cap. & 665 & 290 & $+375^{* * *}$ \\
\hline Idem in border districts ${ }^{d}$ & 593 & 311 & $+282^{* * *}$ \\
\hline Official: Cocoa + Coffee $^{c}$ prod. income p.c. & 123 & 10 & +113 \\
\hline Survey: Cocoa + Coffee income per cap. & 95 & 8 & $+87 * * *$ \\
\hline Idem in border districts $^{d}$ & 192 & 18 & $+174^{* * *}$ \\
\hline \multicolumn{4}{|l|}{1993} \\
\hline Official: Consumption ${ }^{a}$ per cap. & 505 & 341 & +164 \\
\hline Survey: Consumption ${ }^{b}$ per cap. & 417 & 323 & $+94^{* * *}$ \\
\hline Idem in border districts ${ }^{d}$ & 350 & 274 & $+76^{* * *}$ \\
\hline Official: Cocoa + Coffee $^{c}$ prod. income p.c. & 42 & 7 & +35 \\
\hline Survey: Cocoa + Coffee income p.c. & 29 & 5 & $+24 * * *$ \\
\hline \multirow[t]{2}{*}{ Idem in border districts ${ }^{d}$} & 30 & 13 & $+17^{* * *}$ \\
\hline & Côte d'Ivoire & Mali & Diff. $^{e}$ \\
\hline \multicolumn{4}{|l|}{1993} \\
\hline Official: Consumption ${ }^{a}$ per cap. & 575 & 237 & +338 \\
\hline Survey: Cash expenditures ${ }^{b}$ per cap. & 395 & 174 & $+221^{* * *}$ \\
\hline Idem in border districts $d$ & 188 & 79 & $+110^{* * *}$ \\
\hline Official: Cotton $^{c}$ income per cap. & 5 & 8 & +2 \\
\hline Survey: Cotton income per cap. & 7 & 7 & 0 \\
\hline Idem in border districts ${ }^{d}$ & 57 & 14 & $+43^{* * *}$ \\
\hline
\end{tabular}

Source: Authors' analysis based on data described in the text.

Notes: Figures in US dollars. Top panel (Ghana): 1988 prices and exchange rates. Bottom panel (Mali): 1993 prices and exch. rates. 1986-8: Averages of 1986-8.

a: National accounts household final consumption expenditure per capita.Source: World Bank 2012.

b: Top panel (Ghana): Household consumption per capita, including consumed own food production. Bottom panel (Mali): Household cash expenditures per capita.

c: Cocoa beans, green coffee, or seed cotton output multiplied by the corresponding producer price and divided by total population. Source: FAOSTAT 2012.

d: Administrative districts lying along the border. Ghana border: Abengourou, Aboisso, Agnibilékrou, Bondoukou, Tanda (Côte d'Ivoire side); Western and Brong-Ahafo (Ghana side). Mali border: Boundiali, Ferkessédougou, Korhogo, Odienné, and Tingréla; Bougouni, Kadiolo, Kolondiéba and Yanfolila. See also map S2.1 in the supplemental online appendix.

e: Difference between the first and second columns. For survey means comparisons, errors are clustered by PSUs: ***: $p<.01$; **: $p<.05 ; *: p<.10$ 
over the Akan ethnic group variable because the GLSS1 survey for 1987 Ghana has many (non-random) missing values for ethnicity.

Table 3: Discontinuities at the border of Côte d'Ivoire with Ghana

\begin{tabular}{|c|c|c|c|c|c|c|c|}
\hline \multirow[b]{2}{*}{ Bandwidth in $\mathrm{km}$ : } & \multirow{2}{*}{$\begin{array}{l}\text { Nat. } \\
(1)\end{array}$} & \multicolumn{2}{|c|}{ Linear RD } & \multicolumn{2}{|c|}{ Polynomial } & \multicolumn{2}{|c|}{ Matching } \\
\hline & & $\begin{array}{c}50 \\
(2 \mathrm{a})\end{array}$ & $\begin{array}{c}75 \\
(2 \mathrm{~b})\end{array}$ & $\begin{array}{c}50 \\
(3 a)\end{array}$ & $\begin{array}{c}75 \\
(3 \mathrm{~b})\end{array}$ & $\begin{array}{c}50 \\
(4 a)\end{array}$ & $\begin{array}{c}75 \\
(4 \mathrm{~b})\end{array}$ \\
\hline \multicolumn{8}{|l|}{$1986-8$} \\
\hline Log. Consumption p. c. & $\begin{array}{c}+0.75^{* * *} \\
(0.04)\end{array}$ & $\begin{array}{c}+0.74^{* * *} \\
(0.23)\end{array}$ & $\begin{array}{c}+0.64^{* * *} \\
(0.15)\end{array}$ & $\begin{array}{c}+0.79^{* * *} \\
(0.23)\end{array}$ & $\begin{array}{c}+0.65^{* * *} \\
(0.15)\end{array}$ & $\begin{array}{c}+0.68^{* * *} \\
(0.07)\end{array}$ & $\begin{array}{c}+0.68^{* * *} \\
(0.07)\end{array}$ \\
\hline Head born in border ${ }^{a}$ & & $\begin{array}{c}+0.85^{* * *} \\
(0.18)\end{array}$ & $\begin{array}{c}+0.68^{* * *} \\
(0.14)\end{array}$ & $\begin{array}{c}+0.93^{* * *} \\
(0.18)\end{array}$ & $\begin{array}{c}+0.70^{* * *} \\
(0.15)\end{array}$ & $\begin{array}{c}+0.77^{* * * *} \\
(0.05)\end{array}$ & $\begin{array}{c}+0.72^{* * *} \\
(0.04)\end{array}$ \\
\hline Log. Expenditures p. c. & $\begin{array}{c}+0.82^{* * *} \\
(0.07)\end{array}$ & $\begin{array}{c}+0.57^{*} \\
(0.34)\end{array}$ & $\begin{array}{c}+0.67^{* * *} \\
(0.25)\end{array}$ & $\begin{array}{c}+0.70^{* *} \\
(0.30)\end{array}$ & $\begin{array}{c}+0.57^{* *} \\
(0.24)\end{array}$ & $\begin{array}{c}+0.54^{* * * *} \\
(0.13)\end{array}$ & $\begin{array}{c}+0.65^{* * *} \\
(0.12)\end{array}$ \\
\hline Head born in border ${ }^{a}$ & & $\begin{array}{l}+0.45 \\
(0.28)\end{array}$ & $\begin{array}{c}+0.49^{* *} \\
(0.22)\end{array}$ & $\begin{array}{c}+0.65^{* *} \\
(0.26)\end{array}$ & $\begin{array}{c}+0.47^{*} \\
(0.24)\end{array}$ & $\begin{array}{c}+0.41^{* *} \\
(0.16)\end{array}$ & $\begin{array}{c}+0.54^{* * *} \\
(0.10)\end{array}$ \\
\hline Stunted 6-59 m. (\%) & $\begin{array}{c}-12^{* * *} \\
(1)\end{array}$ & $\begin{array}{c}-38^{* * *} \\
(8)\end{array}$ & $\begin{array}{c}-25^{* * *} \\
(8)\end{array}$ & $\begin{array}{c}-44^{* * *} \\
(9)\end{array}$ & $\begin{array}{c}-35^{* * *} \\
(9)\end{array}$ & $\begin{array}{c}-37^{* * *} \\
(6)\end{array}$ & $\begin{array}{c}-29^{* * *} \\
(3)\end{array}$ \\
\hline Head born in border ${ }^{a}$ & & $\begin{array}{c}-33^{* * *} \\
(8)\end{array}$ & $\begin{array}{l}-11 \\
(7)\end{array}$ & $\begin{array}{c}-35^{* * *} \\
(9)\end{array}$ & $\begin{array}{c}-23^{* * *} \\
(8)\end{array}$ & $\begin{array}{c}-26^{* * *} \\
(4)\end{array}$ & $\begin{array}{c}-17^{* * *} \\
(2)\end{array}$ \\
\hline Stunted 6-35 m. (\%) & $\begin{array}{c}-6^{* * * *} \\
(2)\end{array}$ & $\begin{array}{c}-26^{* * *} \\
(7)\end{array}$ & $\begin{array}{c}-16^{* *} \\
(6)\end{array}$ & $\begin{array}{c}-32^{* * * *} \\
(9)\end{array}$ & $\begin{array}{c}-27^{* * * *} \\
(8)\end{array}$ & $\begin{array}{c}-28^{* * *} \\
(5)\end{array}$ & $\begin{array}{c}-21^{* * *} \\
(3)\end{array}$ \\
\hline Electricity connection (\%) & $\begin{array}{c}+17^{* * * *} \\
(4)\end{array}$ & $\begin{array}{l}+34 \\
(34)\end{array}$ & $\begin{array}{c}+48^{* *} \\
(22)\end{array}$ & $\begin{array}{l}+29 \\
(32)\end{array}$ & $\begin{array}{c}+33^{*} \\
(19)\end{array}$ & $\begin{array}{l}+31 \\
(19)\end{array}$ & $\begin{array}{c}+36^{* *} \\
(16)\end{array}$ \\
\hline Access to safe water (\%) & $\begin{array}{c}+37^{* * * *} \\
(3)\end{array}$ & $\begin{array}{l}+43 \\
(29)\end{array}$ & $\begin{array}{l}+26 \\
(16)\end{array}$ & $\begin{array}{c}+35^{*} \\
(22)\end{array}$ & $\begin{array}{l}+15 \\
(20)\end{array}$ & $\begin{array}{c}+25^{*} \\
(14)\end{array}$ & $\begin{array}{c}+31^{* * * *} \\
(8)\end{array}$ \\
\hline N C.d'Iv./ N Ghana & $199 / 344$ & $14 / 25$ & $19 / 40$ & $14 / 25$ & $19 / 40$ & $14 / 25$ & $19 / 40$ \\
\hline 1993 & & & & & & & \\
\hline Stunted 6-35 m. (\%) & $\begin{array}{c}+4^{* * *} \\
(2)\end{array}$ & $\begin{array}{c}-1 \\
(10)\end{array}$ & $\begin{array}{l}-6 \\
(9)\end{array}$ & $\begin{array}{l}-1 \\
(9)\end{array}$ & $\begin{array}{l}-4 \\
(8)\end{array}$ & $\begin{array}{l}+8 \\
(8)\end{array}$ & $\begin{array}{l}+6 \\
(7)\end{array}$ \\
\hline Electricity connection (\%) & $\begin{array}{c}+12^{* * *} \\
(3)\end{array}$ & $\begin{array}{c}+35^{* * *} \\
(13)\end{array}$ & $\begin{array}{c}+36^{* * *} \\
(10)\end{array}$ & $\begin{array}{c}+22^{*} \\
(12)\end{array}$ & $\begin{array}{c}+28^{* *} \\
(12)\end{array}$ & $\begin{array}{c}+26^{* *} \\
(12)\end{array}$ & $\begin{array}{c}+26^{* *} \\
(12)\end{array}$ \\
\hline Access to safe water (\%) & $\begin{array}{c}+21^{* * *} \\
(3)\end{array}$ & $\begin{array}{c}+44^{* * * *} \\
(15)\end{array}$ & $\begin{array}{c}+24^{*} \\
(13)\end{array}$ & $\begin{array}{c}+36^{* *} \\
(14)\end{array}$ & $\begin{array}{c}+41^{* * *} \\
(13)\end{array}$ & $\begin{array}{c}+45^{* * * *} \\
(8)\end{array}$ & $\begin{array}{c}+28^{* * * *} \\
(9)\end{array}$ \\
\hline N C.d'Iv./ N Ghana ${ }^{b}$ & $714 / 401$ & $61 / 29$ & $83 / 47$ & $61 / 29$ & $83 / 47$ & $61 / 29$ & $83 / 47$ \\
\hline
\end{tabular}

Source: Authors' analysis based on data described in the text.

Coverage: PSUs in the bandwidth window (50 or $75 \mathrm{~km}$ from the corresponding border).

Notes: Consumption and expenditures at 1988 prices and exchange rates. Col. (2a) to (4b): controls for latitude, rainfalls, elevation, and distance to river are always included.

a: Head born in border: Household head is born in a district lying along the border (see table 2 footnote d).

b: Income survey pooled with DHS data on the Côte d'Ivoire side, DHS only on the Ghana side.

Positive numbers indicate differences in favor of Côte d'Ivoire. Standard errors in parentheses.

***: $p<.01 ; * *: p<.05 ; *: p<.10$

In 1986-8, significant BDs are found for log consumption per capita, ranging from +0.64 to +0.93 (i.e., indicating large income gaps at the border of the two countries) even if we restrict to households whose head is a native of border dis- 
tricts. BDs for log cash expenditures support the same conclusions, although they are lower on average $(+0.41$ to +0.70$)$.

Although we discuss the channels driving these results in more detail in section IV, we need to assess the role of differences in price levels because discontinuities in "nominal" consumption may not match discontinuities in purchasing power. According to the World Bank (2012), in 1988, the price level of private consumption in Côte d'Ivoire was 0.98 that of Ghana, whereas according to the Penn World Tables 7.1 (Heston, Summers and Aten 2012), it was 1.09 at official 1988 exchange rates (i.e., $298 \mathrm{CFA}$ francs and 202 cedis for one US dollar, respectively). After 1983, the Ghanaian government began a gradual process of devaluation of the cedi that ended with free float in 1990 and the elimination of the black market premium. In 1988, the parallel market exchange rate was estimated at 252 cedis/USD. ${ }^{8}$ Using this parallel exchange rate instead of the official one would enhance the border discontinuities in consumption by a factor of $1.25(=252 / 202)$. Thus, it is hardly plausible that the real exchange rate holding in border areas could reverse the conclusion of a large discontinuity in real consumption per capita. ${ }^{9}$

Furthermore, the figures for the share of stunted children are consistent with the Côte d'Ivoire advantage in consumption. For children six months to four years of age, we find large and robust BDs, ranging between 19 and 44 percentage points, with only one exception (linear RD with $75 \mathrm{~km}$ bw and heads born in border districts). For the sub-sample of younger children (6 to 35 months), the point

\footnotetext{
${ }^{8}$ Data from Robert Bates, Karen Feree, James Habyarimana, Macartan Humphreys, and Smita Singh. 2001. "Economic Data (updated 2005)", http://hdl.handle.net/1902.1/14978 UNF:5:8vHsoDT1Q8sUbiTZgDkctw== Murray Research Archive [Distributor] V1 [Version].

${ }^{9}$ In a completely different context, Gopinath, Gourinchas, Hsieh, and Li (2011) find retail and wholesale markets to be segmented at the border between Canada and US. However, relative prices co-move with the nominal exchange rate, so there is little room for changes in the real exchange rate.
} 
estimates lie between 16 and 32 pp. In 1993, which is when income differences at the border must have been reduced to a minimum (see table 2 and above), BDs in early-age stunting are no longer observed. For Côte d'Ivoire, Cogneau and Jedwab (2012) found that the 1990 drastic cut in cocoa producer prices had a large impact on the height of two- to five-year-olds, less so on the youngest.

Finally, BDs for access to electricity seem large in magnitude for most estimates; they are always above 29 percentage points in 1986-8 but suffer from a lack of precision when the smallest $50 \mathrm{~km}$ bandwidth is used. BDs for access to safe water are positive but even less precise. With larger sample sizes on the Côte d'Ivoire side in 1992-3, both are found to lie in the same range and display higher statistical significance. ${ }^{10}$ The results are not shown for the year 1998; despite a small sample on the Ivorian side (11 PSUs only), the results seem to confirm the persistence of the relative superiority of Côte d'Ivoire over Ghana in terms of utilities. ${ }^{11}$

\section{The northern borders}

We now turn to the northern borders of Côte d'Ivoire with Mali and, secondarily, Guinea. $^{12}$

Although 1993 was a very bad year for Côte d'Ivoire, the macroeconomic figures in table 2 show that this country was still far above Mali in terms of household

\footnotetext{
${ }^{10}$ Using DHS data only and for the $75 \mathrm{~km}$ bw, the results are similar, although again less precise due to the smaller sample size (for electricity connection: $+44^{* *},+40^{*},+35$; for water safety: $\left.+27^{*},+44^{* * *},+32^{* *}\right)$.

${ }^{11}$ For the $75 \mathrm{~km}$ bw and for 1998 , the results for electricity connection are $+81^{* * *},+63^{* * *}$, $+48^{* *}$; for water safety: $+30^{*},+20,+19^{* *}$.

${ }^{12}$ In previous versions of this work, we also looked at the border with Burkina Faso. However identification had drawbacks due to sample size and distribution. Borders between northern neighbors were also studied. See supplemental appendix section S3.
} 
consumption per capita, by around +300 USD at 1993 exchange rates and prices. This national account figure is consistent with the survey means comparison for cash expenditures (+221 USD difference), although with some caveats already mentioned. When focusing on administrative districts along the border, the advantage of the Côte d'Ivoire side is halved but remains significant at approximately +110 USD. Even if cotton output per capita was fairly comparable at the national level, the Malian border districts produced very little cotton in 1993, providing a +43 USD per capita advantage to Ivorian districts.

Particularly because of its bauxite resources, Guinea is wealthier than Mali, and the difference from Côte d'Ivoire only reaches +200 USD in consumption per capita (not shown). Furthermore, although mines are not located in the border areas, survey mean comparisons among border districts show that the Guinean side is no poorer than the Ivorian side (not shown).

At the Mali border, discontinuities in log cash expenditures per capita are even higher than those found at the border with Ghana, ranging from +0.84 to +2.02 depending on the estimates, the bandwidth used, and the population considered (table 4 top panel). Recall, however, that the narrower $75 \mathrm{~km}$ bandwidth can be deemed more reliable for identification (see above). With this bandwidth, the upper bound is decreased to +1.52 . The restriction to household heads who are from the Mande-Voltaic group again slightly reduces the estimates by dropping a few Ivorian southerners, such as civil servants sent to the North. ${ }^{13}$ When we ad-

\footnotetext{
${ }^{13}$ The Mande include, in particular, the Bambara, Bobo, Diula, Malinke, and Soussou, whereas the Voltaic or Gur include the Lobi, Mossi, and Senoufo people. The Mande and Voltaic groups are close together in linguistic terms and display some mixing on the map. Ethnic codifications are not homogeneous; in particular, the Malian survey records the language of interview rather than the "ethnic group". However, district of birth is only recorded in the Côte d'Ivoire survey, so we have no alternative.
} 
ditionally withdraw international migrants (i.e., mainly relatively wealthy Malian migrants to Ivorian regional cities such as Korhogo), a slight attenuation is again observed, but the BDs still range between +0.8 and +1.2 .

Table 4: Discontinuities at the border of Côte d'Ivoire with Mali and Guinea

\begin{tabular}{|c|c|c|c|c|c|c|c|}
\hline \multirow[b]{2}{*}{ Bandwidth in km: } & \multirow{2}{*}{$\begin{array}{l}\text { Nat. } \\
(1) \\
\end{array}$} & \multicolumn{2}{|c|}{ Linear RD } & \multicolumn{2}{|c|}{ Polynomial } & \multicolumn{2}{|c|}{ Matching } \\
\hline & & $\begin{array}{l}75 \\
(2 \mathrm{a}) \\
\end{array}$ & $\begin{array}{l}100 \\
(2 b)\end{array}$ & $\begin{array}{c}75 \\
(3 \mathrm{a})\end{array}$ & $\begin{array}{l}100 \\
(3 b)\end{array}$ & $\begin{array}{c}75 \\
(4 a)\end{array}$ & $\begin{array}{l}100 \\
(4 b)\end{array}$ \\
\hline \multicolumn{8}{|l|}{1993 Côte d'Ivoire / Mali } \\
\hline Log. Expenditures p. c. & $\begin{array}{c}+0.89^{* * *} \\
(0.07)\end{array}$ & $\begin{array}{l}+0.91 \\
(0.59)\end{array}$ & $\begin{array}{c}+1.41^{* *} \\
(0.68)\end{array}$ & $\begin{array}{c}+0.90^{* *} \\
(0.34)\end{array}$ & $\begin{array}{c}+1.06^{*} \\
(0.59)\end{array}$ & $\begin{array}{c}+1.52^{* * *} \\
(0.64)\end{array}$ & $\begin{array}{c}+2.02^{* * *} \\
(0.49)\end{array}$ \\
\hline Head "Mande-Voltaic" $a$ & & $\begin{array}{l}+0.93 \\
(0.55)\end{array}$ & $\begin{array}{c}+1.51^{* *} \\
(0.66)\end{array}$ & $\begin{array}{c}+0.87^{* *} \\
(0.30)\end{array}$ & $\begin{array}{c}+1.18^{* *} \\
(0.54)\end{array}$ & $\begin{array}{c}+1.39^{* *} \\
(0.61)\end{array}$ & $\begin{array}{c}+1.88^{* * * *} \\
(0.49)\end{array}$ \\
\hline Head "Mande-V." \& national ${ }^{a}$ & & $\begin{array}{l}+0.84 \\
(0.56)\end{array}$ & $\begin{array}{c}+1.45^{* *} \\
(0.67)\end{array}$ & $\begin{array}{c}+0.76^{* *} \\
(0.35)\end{array}$ & $\begin{array}{c}+1.10^{* *} \\
(0.55)\end{array}$ & $\begin{array}{c}+1.21^{*} \\
(0.61)\end{array}$ & $\begin{array}{c}+1.70^{* * *} \\
(0.50)\end{array}$ \\
\hline Stunted 6-59 m. (\%) & $\begin{array}{l}+2 \\
(2)\end{array}$ & $\begin{array}{c}-13^{*} \\
(7)\end{array}$ & $\begin{array}{l}-3 \\
(9)\end{array}$ & $\begin{array}{c}-21^{* * *} \\
(6)\end{array}$ & $\begin{array}{c}-16^{* * *} \\
(6)\end{array}$ & $\begin{array}{c}-20^{* *} \\
(7)\end{array}$ & $\begin{array}{c}-16^{* *} \\
(8)\end{array}$ \\
\hline Head "Mande-Voltaic" $a$ & & $\begin{array}{c}-14^{* *} \\
(7)\end{array}$ & $\begin{array}{l}-7 \\
(9)\end{array}$ & $\begin{array}{c}-21^{* * *} \\
(5)\end{array}$ & $\begin{array}{c}-16^{* * *} \\
(5)\end{array}$ & $\begin{array}{c}-18^{* *} \\
(8)\end{array}$ & $\begin{array}{c}-16^{* *} \\
(8)\end{array}$ \\
\hline Head "Mande-V." \& national ${ }^{a}$ & & $\begin{array}{c}-13^{*} \\
(7)\end{array}$ & $\begin{array}{l}-4 \\
(12)\end{array}$ & $\begin{array}{c}-17^{*} \\
(9)\end{array}$ & $\begin{array}{c}-15^{* *} \\
(7)\end{array}$ & $\begin{array}{c}-18^{* *} \\
(8)\end{array}$ & $\begin{array}{l}-16 \\
(11)\end{array}$ \\
\hline Electricity connection (\%) & $\begin{array}{c}+36^{* * *} \\
(2)\end{array}$ & $\begin{array}{l}+10 \\
(11)\end{array}$ & $\begin{array}{c}+9 \\
(13)\end{array}$ & $\begin{array}{l}+15 \\
(15)\end{array}$ & $\begin{array}{l}+16 \\
(12)\end{array}$ & $\begin{array}{l}-1 \\
(6)\end{array}$ & $\begin{array}{c}+1 \\
(12)\end{array}$ \\
\hline N C. d'Iv. / N Mali & $468 / 473$ & $13 / 11$ & $32 / 31$ & $13 / 11$ & $32 / 31$ & $13 / 11$ & $32 / 31$ \\
\hline 1993 Côte d'Ivoire / Guinea & & & & & & & \\
\hline Log. Expenditures p. c. & $\begin{array}{c}+0.44^{* * *} \\
(0.07)\end{array}$ & $\begin{array}{l}-0.03 \\
(0.53)\end{array}$ & $\begin{array}{l}-0.28 \\
(0.64)\end{array}$ & $\begin{array}{l}-0.08 \\
(0.68)\end{array}$ & $\begin{array}{l}+0.31 \\
(0.62)\end{array}$ & $\begin{array}{l}-0.07 \\
(0.32)\end{array}$ & $\begin{array}{l}-0.42 \\
(0.38)\end{array}$ \\
\hline Stunted 6-59 m. (\%) & $\begin{array}{c}+12^{* * *} \\
(2)\end{array}$ & $\begin{array}{l}+23 \\
(22)\end{array}$ & $\begin{array}{l}+29 \\
(22)\end{array}$ & $\begin{array}{l}+14 \\
(16)\end{array}$ & $\begin{array}{l}+5 \\
(19)\end{array}$ & $\begin{array}{l}+11 \\
(11)\end{array}$ & $\begin{array}{l}+17 \\
(17)\end{array}$ \\
\hline Electricity connection (\%) & $\begin{array}{c}+21^{* * *} \\
(3)\end{array}$ & $\begin{array}{l}+30 \\
(20)\end{array}$ & $\begin{array}{l}+14 \\
(22)\end{array}$ & $\begin{array}{l}+11 \\
(14)\end{array}$ & $\begin{array}{c}+35^{*} \\
(21)\end{array}$ & $\begin{array}{c}+10 \\
(6)\end{array}$ & $\begin{array}{l}+9 \\
(8)\end{array}$ \\
\hline N C.d'Iv. / N Guinea & $468 / 312$ & $27 / 22$ & $37 / 28$ & $27 / 22$ & $37 / 28$ & $27 / 22$ & $37 / 28$ \\
\hline
\end{tabular}

Source: Authors' analysis based on data described in the text.

Coverage: PSUs in the bandwidth window (50 or $75 \mathrm{~km}$ from the corresponding border).

Notes: In the cases of "Border RD" and "Matching RD" and for $100 \mathrm{~km}$ bandwidth (col. 2b \& 4b), sample sizes allow for using a quadratic in distance to border rather than a simple linear specification. Col. (2a) to (4b): controls for longitude (Mali) or latitude (Guinea), rainfalls, elevation, and distance to river are always included. a: Head from a Mande or a Voltaic linguistic group. National: excluding foreign immigrants.

Positive numbers indicate differences in favor of Côte d'Ivoire. Standard errors in parentheses. ***: $p<.01 ; * *: p<.05 ; *: p<.10$

Here, monetary welfare comparisons are facilitated by the fact that the two countries share the same currency, namely the CFA franc. We acknowledge that the BDs in nominal consumption may mix discontinuities in real terms and in 
price levels. However, although cattle is a traditional export of northern countries and kola nut is a traditional export of forested Côte d'Ivoire, many goods flow one way or another across the border depending on market demand (e.g., cereals such as rice or millet, textiles, spare parts, etc.), so persistent price differentials should be limited (Labazée 1993). At the national level, World Bank (2012) figures for the year 1993 indicate that the price level of private consumption was lower in Mali by a factor of 0.81; Heston, Summers, and Aten (2012) report a ratio of 0.75. Even if they prevailed at the border, these orders of magnitude would not cancel out the large BDs in real consumption. The devaluation of the CFA franc in 1994 creates an additional difficulty in the comparison because the Malian income survey was implemented in the middle of this year (between March and June), whereas the Ivorian survey was conducted over 1992 and 1993. As already mentioned, monthly prices were used to correct for inflation. The average deflator for cash expenditures in Mali (i.e., the ratio of 1993 prices to current prices) is 0.90, indicating a $10 \%$ inflation rate six months after the $50 \%$ devaluation. Again, we checked that the Côte d'Ivoire advantage was preserved even when we do not deflate the consumption and income variables for Mali.

Furthermore, the BDs for the share of stunted children are again consistent with consumption figures, whereas no difference in national averages is observed. In addition to income, climate and ecology strongly determine height in Africa (Moradi 2012). In West Africa, all anthropometric data confirm that people from the savannah are taller than people from the forest because of the protein intake they obtain from milk and meat (cattle breeding is constrained in the South by the presence of the tsetse fly). In the Malian survey, children from the North were taller than children born close to the Côte d'Ivoire border. Thus, when restricting 
the comparison to the same ecological area, we recover large BDs in nutrition: within our preferred $75 \mathrm{~km}$ bandwidth, children from the Côte d'Ivoire side are 13 to $21 \mathrm{pp}$ less likely to be stunted. The next section will provide some evidence that the bulk of this discontinuity can be explained by parental income.

Finally, whereas the average Ivorian household is $36 \mathrm{pp}$ more likely to have electricity compared to its Malian counterparts (col.1), we find no evidence of a discontinuity in electrification at the border.

In the case of the border with Guinea, no BDs in consumption per capita, stunting, or access to electricity are found (bottom panel of table 4).

\section{The role of public policies}

We argue that two main factors determine the presence or absence of discontinuities in welfare at the borders of Côte d'Ivoire with its neighbors. The first factor lies in the public policies that regulate the cash crop sectors (here, cocoa, coffee, and cotton), either through administered producer prices or through agricultural extension and subsidies to production. The second factor is public investment, either national or local, in infrastructures and utilities such as electricity and safe water.

Because cash crop income is mainly derived from rural areas, whereas utilities initially reach cities, we introduce the urban structure into the analysis. This approach also allows us to test the robustness of our BD estimates. We use a variable already considered in the subsection dedicated to geography, the distance to cities with more than 5,000 inhabitants in 1990. Due to sample size constraints, we only distinguish two urbanization classes: 0 to $5 \mathrm{~km}$ from a city and $5 \mathrm{~km}$ or 
more. We then compute new "matching RD" estimates with PSUs matched with the nearest neighbor from the same class. ${ }^{14}$ We report matching RD estimates for the whole sample ("All") and for the sample restricted to remote rural areas ("5+"); we do this for our preferred $75 \mathrm{~km}$ bandwidth. The results show that the "All" and " $5+$ " estimates look very much the same. Indeed, cities or peri-urban areas ("0-5") are seldom found close to the borders, and it is mainly differences between remote rural areas that "make" the border discontinuities (table 5). In addition to this "urban/rural" breakdown, we report BD estimates for cash crop output and income.

At the border with Ghana (1986-8), BDs in log cash expenditures are very robust to the breakdown between urban/peri-urban $(0-5 \mathrm{~km})$ and remote rural $(5+$ $\mathrm{km}$ ) localities. For the whole sample (col.1a), the matching RD estimate of +0.62 compares with the initial finding of +0.65 in table 3 col.(4b). When restricting to rural areas (col.1b), it decreases to +0.52 but remains highly significant. At the border with Mali (1993), where a large majority of PSUs is rural, the same restriction leads ato a significant $\mathrm{BD}$ of +0.86 in log cash expenditures (col.2b). At the border of Guinea (1993-4), it is still the case that no discontinuity is detected (col.3).

We now turn to cash crop output and income.

At the Ghana border, no discontinuity in cocoa output is detected; both sides are important cocoa production areas at that time. ${ }^{15}$ However, the real producer price for cocoa in Côte d'Ivoire is more than twice that of Ghana: at 1988 prices,

\footnotetext{
${ }^{14}$ For the rest, the estimation is kept the same; see equation (4). In the case of the Mali border, where only five urban or peri-urban PSUs are found in the 75 bandwidth, we match these five PSUs with the nearest neighbor, regardless of its urbanization class. See also table 5 footnote.

${ }^{15}$ At the national level, the Ivorian superiority in cocoa output is due to the younger trees of the central and western regions, not to the eastern border area.
} 
Table 5: The cash crops channel

\begin{tabular}{|c|c|c|c|c|c|}
\hline \multirow{4}{*}{$\begin{array}{l}\text { Distance to city in } \mathrm{km} \text { : } \\
\text { Bandwidth in } \mathrm{km} \text { : }\end{array}$} & \multicolumn{2}{|c|}{$\begin{array}{l}\text { Ghana } \\
1986-8\end{array}$} & \multicolumn{2}{|c|}{$\begin{array}{l}\text { Mali } \\
1993\end{array}$} & \multirow{3}{*}{$\begin{array}{c}\text { Guinea } \\
1993 \\
\text { All } \\
75\end{array}$} \\
\hline & All & $5+$ & All & $5+$ & \\
\hline & 75 & 75 & 75 & 75 & \\
\hline & (1a) & $(1 b)$ & $(2 \mathrm{a})$ & $(2 \mathrm{~b})$ & $(3)$ \\
\hline Log. Expenditures per capita & $\begin{array}{c}+0.62^{* * *} \\
(0.13)\end{array}$ & $\begin{array}{l}+0.52^{* * *} \\
(0.13)\end{array}$ & $\begin{array}{l}+1.52^{* * *} \\
(0.64)\end{array}$ & $\begin{array}{c}+0.86^{* *} \\
(0.31)\end{array}$ & $\begin{array}{l}-0.22 \\
(0.22)\end{array}$ \\
\hline Main cash crop $^{c}$ output p.c. (kg) & $\begin{array}{l}+29 \\
(30)\end{array}$ & $\begin{array}{l}+23 \\
(46)\end{array}$ & $\begin{array}{c}+733^{* * *} \\
(211)\end{array}$ & $\begin{array}{c}+664^{* * *} \\
(84)\end{array}$ & $\begin{array}{c}+9^{* *} \\
(3)\end{array}$ \\
\hline Cash $\operatorname{crops}^{b}$ income p.c. (USD) ${ }^{a}$ & $\begin{array}{c}+194^{* * *} \\
\quad(43)\end{array}$ & $\begin{array}{c}+184^{* * * *} \\
\quad(65)\end{array}$ & $\begin{array}{c}+237^{* * *} \\
(68)\end{array}$ & $\begin{array}{l}+214^{* * *} \\
\quad(27)\end{array}$ & $\begin{array}{c}+16^{* * * *} \\
(2)\end{array}$ \\
\hline Cash Expenditures per capita (USD) ${ }^{a}$ & $\begin{array}{c}+177^{* * * *} \\
\quad(52)\end{array}$ & $\begin{array}{c}+120^{* *} \\
(48)\end{array}$ & $\begin{array}{c}+173^{* *} \\
(61)\end{array}$ & $\begin{array}{c}+117^{* * * *} \\
(38)\end{array}$ & $\begin{array}{c}+2 \\
(37)\end{array}$ \\
\hline Cash crops inc. controlled ${ }^{d}$ & $\begin{array}{c}+135 \\
(99)\end{array}$ & $\begin{array}{l}-2 \\
(77)\end{array}$ & $\begin{array}{r}+48 \\
(56)\end{array}$ & $\begin{array}{l}-13 \\
(32)\end{array}$ & $\begin{array}{l}+63 \\
(64)\end{array}$ \\
\hline Cash crops \& wage inc. controlled ${ }^{e}$ & $\begin{array}{l}+21 \\
(53)\end{array}$ & $\begin{array}{c}-1 \\
(65)\end{array}$ & $\begin{array}{l}+39 \\
(53)\end{array}$ & $\begin{array}{l}-13 \\
(39)\end{array}$ & $\begin{array}{l}-31 \\
(20)\end{array}$ \\
\hline Stunted 6-59 months (\%) & $\begin{array}{c}-26^{* * *} \\
(6)\end{array}$ & $\begin{array}{c}-32 * * * \\
(5)\end{array}$ & $\begin{array}{c}-20^{* *} \\
(7)\end{array}$ & $\begin{array}{c}-24 * * * \\
(7)\end{array}$ & $\begin{array}{l}+16 \\
(13)\end{array}$ \\
\hline Expend. per cap. controlled ${ }^{f}$ & $\begin{array}{l}-10 \\
(7)\end{array}$ & $\begin{array}{l}-8 \\
(5)\end{array}$ & $\begin{array}{l}-5 \\
(12)\end{array}$ & $\begin{array}{l}-8 \\
(14)\end{array}$ & $\begin{array}{l}+14 \\
(13)\end{array}$ \\
\hline Electricity connection $^{g}(\%)$ & $\begin{array}{c}+28^{* *} \\
(13)\end{array}$ & $\begin{array}{c}+22^{*} \\
(11)\end{array}$ & $\begin{array}{l}-2 \\
(6)\end{array}$ & $\begin{array}{l}-6 \\
(4)\end{array}$ & $\begin{array}{l}+0 \\
(4)\end{array}$ \\
\hline $\mathrm{N}$ & $19 / 40$ & $10 / 30$ & $13 / 11$ & $10 / 9$ & $27 / 22$ \\
\hline
\end{tabular}

Source: Authors' analysis based on data described in the text.

Coverage: PSUs in the $75 \mathrm{~km}$ bandwidth window.

Notes: "Matching RD" estimates with $75 \mathrm{~km}$ bandwidth. PSUs are matched to the nearest neighbor on the other side of the border within the same urbanization class: $0-5 \mathrm{~km}$ or $5+\mathrm{km}$ from the nearest city $(5,000+$ inhabitants) as of 1990. Matched differences are then analyzed as in equation (4) (see text). In the case of the Mali border, where only 5 PSUs are in the 0-5 km class, the "All" estimate (col.2a) does not match PSUs according to class, it is therefore exactly the same as in Table 4 col. (4a). Controls for latitude (Ghana and Guinea) or longitude (Mali), rainfalls, elevation, and distance to river are always included.

a: 1988 prices and exchange rates in columns (1a-b); 1993 prices and exchange rates in col. (2a-b) and (3).

b: Cocoa and coffee sales in (1a-b) and (3); Cotton output valued at official producer price in (2a-b).

c: Cocoa output sold in col. (1a-b) and (3); Cotton output in col. (2a-b). Kilograms per capita.

d: Cash expenditures per capita border discontinuity, with cash crop income per capita added as a control.

e: Idem d, with instead the sum of cash crop and wage income per capita as a control.

f: Stunted children discontinuity, with cash expenditures per capita and its square added as controls.

g: At the border with Ghana in 1992-3 and for electricity connection: 'All': +30** (s.e. 13); '5+': +37** (16).

Positive numbers indicate differences in favor of Côte d'Ivoire. Standard errors in parentheses.

$* * *: p<.01 ; * *: p<.05 ; *: p<.10$ 
the average real producer price for $1986-8$ is 1.55 USD per kg in the former country compared with 0.65 in the latter. In contrast, in the case of coffee, a large BD in output is observed because this crop is not produced in Ghana due to historically low administered producer prices in this country. Among rural villages, we therefore find a large BD in cocoa and coffee income of +184 USD per capita (table 5, col. 1b). Additional disaggregation (not shown) shows that cocoa accounts for two-thirds and coffee for the remaining one-third. Before 1990, the cocoa producer price differential generated a strong incentive to smuggle cocoa beans across the Côte d'Ivoire border (Bulír 1998). However, our BD result suggests that smuggling was not widespread enough to equalize incomes across the border. When the cash crop income variable is added as a control in the BD estimates, the BD in cash expenditures that prevails among rural villages is strikingly erased, decreasing from +120 USD to a negligible -2 USD. Recall that expenditures and income figures are drawn from two independent parts of the surveys' questionnaires. ${ }^{16}$ When including cities and peri-urban villages (col. 1a), the cash expenditure discontinuity is only reduced from +177 to +135 USD, although it becomes statistically insignificant. However, if we add formal wage income earned by household members to cash crop income, then controlling for this new income variable successfully reduces the cash expenditures $\mathrm{BD}$ to a low and insignificant +21 USD. ${ }^{17}$

At the Mali border, we detect a very large BD in cotton output per capita of $+664 \mathrm{~kg}$ per capita among rural villages (col.2b). In contrast with the Ghana

\footnotetext{
${ }^{16}$ This procedure involves assuming that (i) the same saving rate applies to cash crop income on both border sides and (ii) this saving rate is consistently estimated by OLS.

${ }^{17}$ In 1986-8, the survey figures for the average annual wage of civil servants and public firms workers reached 5,223 USD in Côte d'Ivoire compared with 663 USD in Ghana. For private firm workers, they were 3,498 USD and 540 USD, respectively. The minimum wage in Côte d'Ivoire (1,400 USD) was also six times higher than in Ghana (240 USD).
} 
border, the BD in cotton income mainly stems from a higher output on the Côte d'Ivoire side because producer prices are only slightly higher (90 vs. 85 CFA franc per kg in Mali). Further, this Ivorian advantage is specific to the border area; both national official sales and survey figures show that the two countries produced roughly the same quantities of cotton (see table 2). In fact, the Mali side of the border was not yet producing significant quantities of cotton. In this country, cotton production historically began more northward, around the city of Koutiala, and mostly took off in the mid-1970s. As in Côte d'Ivoire, it was strongly regulated and subsidized by the State through a parastatal company (Compagnie Malienne de Développement des Textiles). We can again explain the $\mathrm{BD}$ in consumption among rural villages by the discontinuity in cash crop income. As in the case of Ghana (with cocoa and coffee), when controlling for cotton income, the BD in cash expenditures decreases from +117 USD to an insignificant -13 . Unreported results also show that richer farmers invest in cattle. We identify BDs in the number of cows owned by the household $(+1.76$, s.e. $=0.32)$ as well as in the number of goats and sheep $(+0.53$, s.e. $=0.10)$. Differences in public health policies may also be involved because the fight against parasitic diseases (river blindness or onchocerciasis, sleeping sickness or trypanosomiasis) was undertaken much earlier in Côte d'Ivoire.

At the Guinea border, although almost no cocoa and approximately half as much coffee is grown on the Guinea side, the BD in cash crops income is small but statistically significant (+16 USD). In comparison with the Ghana and Mali cases, we argue that the absence of a large difference in cash crop income may account for why no border discontinuity is found in consumption per capita or in children's stunting. 
Regarding this latter variable, table 5 also suggests that a large part of the BDs can be accounted for by household consumption. In the Ghana case, controlling for cash expenditures per capita and its square reduces the BD in stunting from -32 among rural villages (-26 in the whole sample) to an insignificant -8 percent $(-10$ in the whole sample). In the Mali case, the same dramatic reduction is observed, from -24 in rural villages to -8 percent ( -20 to -5 in the whole sample). Combined with the results obtained on the impact of cash crop income, this last result lends some support to the idea that the cash crop channel explains most of the border discontinuities in both household consumption and child nutrition.

In the Ghana case, electricity reaches border rural villages on the Côte d'Ivoire side, whereas none of their Ghanaian counterparts is connected. This simple fact translates into a significant +22 -percentage-point BD $(+28$ pp in the whole sample, see last row of table 5). In 1993, these BDs were reinforced: +37 pp in rural areas and +30 in the whole sample (see table 5 footnote). The same features are found for access to safe water. In contrast, at the two other borders, all remote rural areas are in the dark. Although Ivorian regional cities are more connected to electricity than their northern counterparts, they are too far from the border to significantly contribute to the BDs. In explaining these features, it is difficult to disentangle a pure wealth effect from a more discretionary uneven allocation of public investment. ${ }^{18}$

Recent history shows that price policies were reverted during structural adjustment under pressure from donors. In 1989-90, Côte d'Ivoire halved both its cocoa and coffee producer prices before raising them again after the CFA franc

\footnotetext{
${ }^{18}$ Although wealthier, northern Ivorian households may not be wealthy enough to pay for electricity connection.
} 
devaluation in 1994. In the meantime, Ghana significantly raised its cocoa producer price so that the difference between the two countries became negligible at the end of the 1990s. Changes in cash crop production were slower, but they also occurred. Between 1994 and 2001, Mali more than doubled its cotton production in the South through the extensive cultivation of new lands; however, the cultivation of cotton had not yet reached the most southern border area (Dufumier and Bainville 2006). In contrast, the Ivorian "cocoa frontier" has moved westward and today reaches the southern Guinea border. With these developments, some of the border discontinuities that we identified for the 1990s may have changed. After 2002, the civil war in Côte d'Ivoire and the five-year partition between North and South may have further reduced the Ivorian advantage at the northern borders, at least until 2007. In the South, Ghana continued to catch up with its neighbor (Eberhardt and Teal 2010). Hence, although infrastructure showed greater persistence in 1993 and in 1998, border differences may have been attenuated since then. Unfortunately, the data that we gathered do not cover those more recent economic conditions.

\section{Conclusion}

The borders between Côte d'Ivoire and its neighbors divide fairly comparable areas in terms of geography, anthropology, and precolonial history. At the end of the 1980s and in the 1990s, Côte d'Ivoire was by far the wealthiest country, particularly because of its export crops. By applying regression discontinuity designs to a set of household surveys, we show that this higher wealth was translated at the borders with Ghana and Mali in the form of large and consistent discontinu- 
ities in consumption and in child stunting. We provide evidence for the fact that the bulk of these border discontinuities can be explained by cash crop production and/or pricing policies. At the border of Guinea, where no economically significant discontinuity is found in cash crop income, no discontinuity in consumption or nutrition is detected either. At the border of Ghana, we also identify persistent border discontinuities in access to electricity and safe water, even among rural villages, linked to high public investment in southern Côte d'Ivoire. At the northern borders, electricity only reaches Ivorian cities, not rural areas.

Thus, we obtain a balanced conclusion. National borders in West Africa are not highly porous, abstract lines with no impact on the welfare of the communities across them. However, our analysis suggests that border discontinuities reflect reversible public policies rather than intangible institutional traits (although political and structural factors can account for how long it takes to change policies). In rural areas, the discontinuities in consumption stem from differences in cash crop output and earnings. These differences are not necessarily permanent, and they changed during the two past decades because of policy shifts, political shocks, and medium-term agronomic developments. We hope that we have shown that border discontinuities in welfare were observed in the past and may continue to mirror the differences between national policies in the future. 
Appendix Table A.1: Geography at northern borders

\begin{tabular}{|c|c|c|c|c|c|c|}
\hline \multirow[b]{2}{*}{ Bandwidth in km: } & \multicolumn{2}{|c|}{ Linear RD } & \multicolumn{2}{|c|}{ Polynomial RD } & \multicolumn{2}{|c|}{ Matching RD } \\
\hline & 75 & 100 & 75 & 100 & 75 & 100 \\
\hline \multicolumn{7}{|l|}{1993 Côte d'Ivoire / Mali } \\
\hline \multirow[t]{2}{*}{ Relative PSU weights ${ }^{a}$} & -0.19 & -0.51 & -0.17 & $-0.73^{*}$ & -0.24 & $-1.05^{*}$ \\
\hline & $(0.28)$ & $(0.88)$ & $(0.22)$ & $(0.39)$ & $(0.21)$ & $(0.47)$ \\
\hline \multirow[t]{2}{*}{ Rainfall (mm per day $)^{b}$} & -.002 & +.093 & +.062 & +.072 & +.055 & $+.110^{* * *}$ \\
\hline & $(.057)$ & $(.086)$ & $(.070)$ & $(.049)$ & $(.030)$ & $(.029)$ \\
\hline \multirow[t]{2}{*}{ Elevation (meters) } & -18 & -7 & +9 & +1 & +9 & +17 \\
\hline & $(22)$ & $(24)$ & $(16)$ & (13) & (12) & (11) \\
\hline \multirow[t]{2}{*}{ Dist. nearest river $(\mathrm{km})$} & -3.8 & -5.1 & +0.2 & -2.6 & -2.1 & -2.7 \\
\hline & $(3.7)$ & $(4.3)$ & $(4.7)$ & $(2.8)$ & $(2.5)$ & $(3.5)$ \\
\hline \multirow[t]{2}{*}{ Dist. city $5,000+1960(\mathrm{~km})$} & $+26.8^{*}$ & $+50.3^{*}$ & +19.3 & +9.6 & $+33.5^{* *}$ & $+46.2^{* *}$ \\
\hline & $(13.1)$ & $(25.8)$ & $(15.6)$ & $(11.7)$ & $(11.0)$ & $(16.0)$ \\
\hline \multirow[t]{2}{*}{ Dist. city 5,000+ $1990(\mathrm{~km})$} & -7.8 & -6.6 & -13.1 & -11.6 & -10.2 & -9.3 \\
\hline & $(15.7)$ & $(20.4)$ & $(19.7)$ & $(11.8)$ & $(17.6)$ & $(21.0)$ \\
\hline \multirow[t]{2}{*}{ Pop. density 1990 (inh. $/ \mathrm{km}^{2}$ ) } & $+11.2^{* *}$ & $+24.6^{*}$ & $+11.5^{*}$ & $+17.5^{* * *}$ & +7.6 & +11.5 \\
\hline & $(5.0)$ & $(13.0)$ & $(5.6)$ & $(6.4)$ & $(6.4)$ & $(8.4)$ \\
\hline \multirow{2}{*}{ Dist. capital city (km) } & $+290 * * *$ & $+254^{* * *}$ & $+310^{* * *}$ & $+301^{* * *}$ & $+284^{* * *}$ & $271 * * *$ \\
\hline & $(28)$ & $(37)$ & $(30)$ & $(23)$ & $(47)$ & $(56)$ \\
\hline \multicolumn{7}{|l|}{1993 Côte d'Ivoire / Guinea } \\
\hline \multirow[t]{2}{*}{ Relative PSU weights $^{a}$} & -1.01 & -0.09 & -0.43 & -0.27 & -0.24 & -0.18 \\
\hline & $(1.30)$ & $(1.21)$ & $(0.57)$ & $(0.52)$ & $(0.26)$ & $(0.17)$ \\
\hline \multirow[t]{2}{*}{ Rainfall (mm per day $)^{b}$} & -.029 & +.102 & +.093 & -.084 & -.118 & -.054 \\
\hline & $(.087)$ & $(.132)$ & $(.095)$ & $(.079)$ & $(.096)$ & $(.059)$ \\
\hline \multirow[t]{2}{*}{ Elevation (meters) } & $-190 * *$ & -103 & -87 & $-135^{* *}$ & -130 & -80 \\
\hline & $(90)$ & $(115)$ & $(65)$ & $(58)$ & $(72)$ & $(51)$ \\
\hline \multirow[t]{2}{*}{ Dist. nearest river (km) } & $-26.7^{* *}$ & -7.4 & -9.2 & $-22.8^{* *}$ & $-17.5^{*}$ & -7.8 \\
\hline & $(10.6)$ & $(12.6)$ & $(10.0)$ & $(10.5)$ & $(8.5)$ & $(6.7)$ \\
\hline \multirow[t]{2}{*}{ Dist. city $5,000+1960(\mathrm{~km})$} & +9.8 & +57.9 & +19.9 & -23.9 & +7.6 & +44.1 \\
\hline & $(35.4)$ & $(40.0)$ & $(14.6)$ & $(28.2)$ & $(38.4)$ & $(34.8)$ \\
\hline \multirow[t]{2}{*}{ Dist. city 5,000+ $1990(\mathrm{~km})$} & +8.3 & +1.4 & -3.4 & -8.3 & +2.8 & +3.6 \\
\hline & $(18.3)$ & $(23.3)$ & $(18.3)$ & $(15.3)$ & $(9.6)$ & $(10.2)$ \\
\hline \multirow[t]{2}{*}{ Pop. density 1990 (inh. $/ \mathrm{km}^{2}$ ) } & -26.0 & -29.6 & +16.8 & -4.6 & +20.1 & -25.7 \\
\hline & $(20.4)$ & $(25.1)$ & $(23.2)$ & $(17.2)$ & $(16.5)$ & $(22.6)$ \\
\hline \multirow[t]{2}{*}{ Dist. capital city $(\mathrm{km})$} & $-69 * * *$ & $-93^{* * *}$ & $-76^{* * *}$ & $-59 * * *$ & $-60 * * *$ & $-80^{* * *}$ \\
\hline & $(20)$ & $(24)$ & $(20)$ & $(20)$ & $(25)$ & $(19)$ \\
\hline
\end{tabular}

Source: Authors' analysis based on data described in the text.

Coverage: PSUs in the bandwidth window (75 or $100 \mathrm{~km}$ from the corresponding border).

Notes: See equations (2), (3) and (4) for each estimator. For "Border RD" and "Matching RD", the only

control variable is longitude (Mali), or latitude (Guinea). For $100 \mathrm{~km}$ bandwidth, sample sizes allow for using a quadratic in distance to border rather than a simple linear specification.

a, b: See Table 1 .

Positive numbers indicate differences in favor of Côte d'Ivoire. Standard errors in parentheses.

$* * *: p<.01 ; * *: p<.05 ; *: p<.10$ 
Appendix Table A.2: Surveys

\begin{tabular}{|c|c|c|c|c|c|}
\hline Country & Survey name & $\begin{array}{c}\text { Survey } \\
\text { type }\end{array}$ & Period & $\begin{array}{c}\text { \# house- } \\
\text { holds }\end{array}$ & $\begin{array}{l}\text { Geo- } \\
\text { ref.? }\end{array}$ \\
\hline \multicolumn{6}{|l|}{$1986-8$} \\
\hline Côte d'Ivoire & CILSS2-4 & IS & Feb.86-May.89 & 4,814 & Yes \\
\hline Ghana & GLSS1-2 & IS & Mar.87-Apr.89 & 6,336 & Yes \\
\hline \multicolumn{6}{|l|}{$1992-4$} \\
\hline Côte d'Ivoire & ENV1 & IS & Apr.92-Oct.93 & 9,598 & Yes \\
\hline Côte d'Ivoire & DHS 1994 & DHS & Jun.94-Nov.94 & 5,914 & Yes \\
\hline Ghana & DHS 1993 & DHS & Sep.93-Feb.94 & 5,804 & Yes \\
\hline Ghana & GLSS3 & IS & Sep.91-Sep.92 & 6,336 & No \\
\hline Mali & EMCES & IS & Mar.94-June94 & 9,554 & Yes \\
\hline Guinea & EIBC & IS & Jan.94-Feb.95 & 4,417 & Yes \\
\hline \multicolumn{6}{|l|}{1998} \\
\hline Côte d'Ivoire & ENV2 & IS & Sep.98-Dec.98 & 4,178 & No \\
\hline Côte d'Ivoire & DHS 1998-99 & DHS & Sep.98-Mar.99 & 2,115 & Yes \\
\hline Ghana & GLSS4 & IS & Apr.98-Mar.99 & 6,016 & Yes \\
\hline Ghana & DHS 1998 & DHS & Nov.98-Feb.99 & 5,983 & Yes \\
\hline
\end{tabular}

Source: Household survey documents.

Notes: The three first Ivorian (CILSS 2 to 4) and the two first Ghanaian (GLSS 1 and 2) surveys are stacked to obtain large samples covering the $1986-8$ period. IS = Income Survey, LSMS-type. DHS= Demographic and Health Survey. 


\section{References}

Aker, Jenny C., Michael W. Klein, Stephen O'Connell and Muzhe Yang. 2010. "Borders, Ethnicity and Trade". Cambridge (MA): National Bureau of Economic Research Working Paper 15960.

Alesina, Alberto, William Easterly, and Janina Matuszevski. 2012. "Artificial States". Journal of the European Economic Association, 9 (2): 246-277.

Amselle, Jean-Loup and Elikia M'Bokolo (eds). 1985. Au coeur de l'ethnie. Paris: La Découverte.

Asiwaju, A. I. 1976. Western Yorubaland under European Rule, 1889-1945. Atlantic Highlands (NJ): Humanities Press.

Bach, Daniel. 1997. "Frontiers versus Boundary-Lines: changing Patterns of State-Society Interactions in Sub-Saharan Africa". Welttrends, 14: 97-111.

Barbour, Kenneth M. 1961. "A Geographical Analysis of Boundaries in InterTropical Africa". In Barbour K.M. and R.M. Prothero, Essays on African Population, London: Routledge and Kegan Paul, 303-23.

Bloom, David E. and Jeffrey D. Sachs. 1998. "Geography, Demography and Economic Growth in Africa". Brookings Papers on Economic Activity, 1998 (2): 207295.

Brownlie, Ian. 1979. African Boundaries - A Legal and Diplomatic Encyclopaedia. London: C. Hurst and Company, Berkeley and Los Angeles: University of California Press, for the Royal Institute of International Affairs (London). 
Bulír, Aleš. 1998. "The Price Incentive to Smuggle and the Cocoa Supply in Ghana, 1950-96". Washington DC: International Monetary Fund Working Paper $98 / 88$.

Bubb, Ryan, 2012. "The Evolution of Property Rights: State Law or Informal Norms?" New York: New York University Law School, Law and Economics Research Paper Series, WP NO. 12-1.

Cogneau, Denis and Rémi Jedwab. 2012. "Commodity Price Shocks and Child Outcomes: The 1990 Cocoa Crisis in Côte d'Ivoire". Economic Development and Cultural Change, 60 (3): 507-534.

Dell, Melissa. 2010. "The Persistent Effects of Peru's Mining Mita". Econometrica, 78 (6): 1863-1903.

Dufumier, Marc and Sébastien Bainville. 2006. "Le développement agricole du Sud Mali face au désengagement de l'État". Afrique contemporaine, 217: 121-33. Easterly, William and Ross Levine. 1998. "Troubles with the Neighbours: Africa's Problem, Africa's Opportunity". Journal of African Economies, 7 (1):1203-50.

Eberhardt, Markus and Francis Teal. 2010. "Ghana and Côte d'Ivoire: Changing Places." Revue internationale de politique de développement 1: 33-49.

Englebert, Pierre. 2000. State Legitimacy and Development in Africa. London and Boulder: Lynne Rienner Publishers.

Englebert, Pierre, Stacy Tarango and Matthew Carter. 2002. "Dismemberment and Suffocation, a Contribution to the Debate on African Boundaries". Comparative Political Studies, 35 (10): 1093-1118. 
FAOSTAT. 2012. http://faostat3.fao.org/home/index.html

Gibbons, Stephen, Stephen Machin, and Olmo Silva. 2009. "Valuing school quality using boundary discontinuities". London: SERC working paper DP0018, London School of Economics.

Griffiths, Ieuan. 1996. "Permeable boundaries." In Nugent, Paul and A.I. Asiwaju (eds), African Boundaries. Barriers, Conduits and Opportunities. London-New York: Pinter, 65-83.

Gopinath, Gita, Pierre-Olivier Gourinchas, Chang-Tai Hsieh, and Nicholas Li. 2011. "International Prices, Costs, and Markup Differences." American Economic Review, 101 (6): 2450-86.

Hahn, Jinyong, Petra Todd, and Wilbert Van der Klauuw. 2001. "Identification and Estimation of Treatment Effects with a Regression-Discontinuity Design", Econometrica, 69 (1): 201-09.

Hargreaves, John D. 1985. "The Making of African Boundaries: Focus on West Africa". In Asiwaju A.I. (ed), Partitioned Africans, Ethnic Relations Across Africa's International Boundaries 1884-1984. New York: St. Martin's Press.

Herbst, Jeffrey I. 2000. States and Power in Africa: Comparative Lessons in Authority and Control. Princeton University Press.

Heston, Alan, Robert Summers, and Bettina Aten. 2012. "Penn World Table Version 7.1". Center for International Comparisons of Production, Income and Prices at the University of Pennsylvania. 
Huillery, Élise. 2009. "History Matters: The Long Term Impact of Colonial Public Investments in French West Africa". American Economic Journal: Applied Economics, 1 (2): 176-215.

Labazée, Pascal. 1993. "Les échanges entre le Mali, le Burkina Faso et le nord de la Côte d'Ivoire". In Grégoire, Emmanuel, and Pascal Labazée (eds), Grands commerçants d'Afrique de l'Ouest. Logiques et pratiques d'un groupe d'hommes d'affaires contemporain. Paris: Karthala-Orstom, 125-73.

Lee, David S. 2008. "Randomized experiments from non-random selection in US House elections". Journal of Econometrics, 142 (2): 675-697.

Levy, Brian and John Sahr Kpundeh (eds). 2004. Building state capacity in Africa: new approaches, emerging lessons. Washington DC : World Bank.

Lewis, M. Paul (ed). 2009. Ethnologue. 16th Edition. SIL International: Dallas. MacLean, Lauren M. 2010. Informal Institutions and Citizenship in Rural Africa. Risk and Reciprocity in Ghana and Côte d'Ivoire. New York: Cambridge University Press.

McCrary, Justin. 2008. "Manipulation of the Running Variable in the Regression Discontinuity Design: A Density Test". Journal of Econometrics, 142 (2): 698714.

Michalopoulos, Stelios and Elias Papaionnou. 2012. "National Institutions and African Development: Evidence from Partitioned Ethnicities". Cambridge (MA): National Bureau of Economic Research Working Paper 18275. 
Michalopoulos, Stelios, and Elias Papaionnou. 2013. "Pre-colonial Ethnic Institutions and Contemporary African Development". Econometrica, 81 (1): 113-152.

Miguel, Edward. 2004. "Tribe or Nation? Nation-Building and Public Goods in Kenya versus Tanzania". World Politics, 56 (3): 327-362.

Miles, Willian F. S. 1994. Hausaland Divided. Colonialism and Independence in Nigeria and Niger. Ithaca (NY): Cornell University Press.

Moradi, Alexander. 2012. "Climate, height and economic development in subSaharan Africa". Journal of Anthropological Sciences Forum, 90: 1-4.

Murdock, George P. 1959. Africa: Its Peoples and Their Culture History. NewYork: McGraw-Hill Book Company.

Nugent, Paul. 2002. Smugglers, Secessionists and Loyal Citizens on the GhanaTogo Frontier: The Life of the Borderlands since 1914. Athens: Ohio University Press.

Posner, Daniel. 2004. "The political salience of ethnic difference: why Chewas and Tumbukas are allies in Zambia and adversaries in Malawi". American Political Science Review, 98 (4): 529-545.

Posner, Daniel. 2005. Institutions and Ethnic Politics in Africa. New York: Cambridge University Press.

Robinson, James A. 2002. "States and pover in Africa by Jeffrey I. Herbst. A review essay", Journal of Economic Literature, 40 (2): 510-19.

Spolaore, Enrico and Romain Wacziarg. 2005. "Borders and Growth". Journal of Economic Growth, 10: 331-86. 
Schultz, T. Paul. 1998. "Inequality in the distribution of personal income in the world: how it is changing and why". Journal of Population Economics, 11 (3):307344.

Terray, Emmanuel. 1982. "L'économie politique du royaume abron du Gyaman". Cahiers d'études africaines, 22 (87-88): 251-275.

World Bank. 2012. African Development Indicators. Washington DC: World Bank publications. 


\section{Appendix}

This appendix is made of three sections, the first is historical on how borders were drawn (S1), the second is statistical on how variables were constructed from surveys raw data (S2), and the third discusses additional results on the border with Burkina Faso and between Côte d'Ivoire neighbors (S3).

\section{S1. The alignment of boundaries in colonial times ${ }^{19}$}

\section{S1.1. The border between Côte d'Ivoire and Ghana}

The border area between Côte d'Ivoire and Ghana stretches from the lagoon regions bordering the Atlantic Ocean to the savannah in the North. Excepting the lagoon in the extreme South and the Black Volta river in the extreme North, the major part of the border we consider does not follow any natural line.

During the 19th century, the bulk of this border area was controlled by the Ashanti Empire whose capital town Kumasi was located in central present-day Ghana. Then, at the end of the 19th century, the French and British started to extend their domination, from trade posts located on the coast toward the North, by signing protectorate treaties with local kingdoms. The 1870 defeat of France against Prussia allowed Great Britain to extend its influence westward. A territorial exchange of the French trade posts of Grand Bassam and Assinie against British Gambia was even considered at that time. But the Binger expedition and the action of French men who had private interests in the region (Treich-Laplène, Verdier) made France regain the lost ground from 1887 by signing treaties with kingdoms located in the middle part of the border area: Indenie (around Abengourou), Sefwi (around Debiso), Gyaman. Having signed treaties with

\footnotetext{
${ }^{19}$ Excellent research assistance from Marie Bourdaud and Angélique Roblin is gratefully acknowledged.
} 
both colonial powers, this latter kingdom, located around Bondoukou, was finally cut in two halves as early as 1891: The city of Bondoukou was first taken by the British in 1887, then by the French in 1888, then by the Diula leader Samori Toure in 1895; the British reconquered it in July 1897 when called for help by the king of the Gyaman, but the French took their revenge and imposed themselves in October 1897.

The two colonial powers needed around 15 years, from 1889 to 1905, to agree upon a definitive alignment. ${ }^{20}$ Some consideration was given to historical ties between populations, but diplomatic bargaining was the dominant feature. ${ }^{21}$ The 1905 memorandum recording the agreement between arrived at by the British and French governments stated that "any natives who may not be satisfied with the assignment of their village to one of the two Powers shall have, for the period of one year from the 1st April, 1905, the right to emigrate to the other side of the frontier"; after that one year delay, the inhabitants of villages situated near the frontier were no longer authorized to build huts on the other side ${ }^{22}$. So that, in econometric terms, "manipulation of the (country) treatment" had been very much restricted at that time.

Between 1958 and 1970, a secessionist movement reclaimed the independence of the Sanwi kingdom in the most southern part of the border on the Côte d'Ivoire side, with the alleged support of Kwame Nkrumah's Ghana; this movement was toughly repressed by Felix Houphouët-Boigny, the leader of independent Côte d'Ivoire. In 1970, a bilateral commission reexamined the border alignment and achieved its works in 1976. The layout of the last demarcation on the field, with teak trees, beacons and pillars, was achieved in 1984 on the Côte d'Ivoire side, and in 1988 on the Ghana side.

\footnotetext{
${ }^{20}$ Brownlie, I., 1979. African Boundaries - A Legal and Diplomatic Encyclopaedia, London: C. Hurst and Company, Berkeley and Los Angeles: University of California Press, for the Royal Institute of International Affairs (London), pp. 231-246.

${ }^{21}$ Stary B., 2003. "Un no man's land forestier de l'artifice à l'artificialité: l'étatisation de la frontière Côte d'Ivoire-Ghana". Cahiers d'Outre-Mer, 222: 199-228.

${ }^{22}$ Brownlie, op. cit. p. 246
} 


\section{S1.2. The border between Côte d'Ivoire and Guinea}

The northern part of this border was laid out in the context of the first war against the Almami Samori Toure whose "first empire" was centered on Kankan and extended southward in present-day Sierra Leone, eastward to Odienne, and northward to the banks of river Niger near Bamako where the French had just arrived, coming from Senegal. ${ }^{23}$ Between 1891 and 1894, the French conquered the regions of Kankan and Beyla that were first included in French Soudan, then in 1899 merged with the other French conquests on the Western coast (1893-94) and in the Fouta Djallon mountains (1896-97) to form the Guinea colony. A sector of this border follows the Feredougouba river.

The southern border area is a forest and mountainous region, which currently corresponds to the districts of Biankouma and Danane in Côte d'Ivoire, Lola and Nzerekore in Guinea. The conquest of this remote forest area by the French began from the North: according to the Berlin treaty this area should have been controlled by Liberia and was not, so that France invaded it gradually and definitely annexed it in 1907. In 1911, the region ceased to be a special military zone and was merged with the rest of the Guinea colony. Because of the resistance from the Guerze people, the French military forces reached the most southern part of the Côte d'Ivoire / Guinea border only as late as in 1908.

There is no detailed description of the border alignment between Côte d'Ivoire and Guinea, whether in French colonial enactments, or in international agreements since independence. ${ }^{24}$ No demarcation is known to have taken place, so that French maps still provide the best available evidence, revealing that some sectors are still indefinite. However no dispute has ever been reported between the two countries.

\footnotetext{
${ }^{23}$ Curtin, P., S. Feierman, L. Thomson and J. Vansina, 1978. African History, From Earliest Times to Independence, Harlow, England: Longman, 2nd edition 1995, p.349.

${ }^{24}$ Brownlie, op.cit., pp.301-303.
} 


\section{S1.3. The borders of Côte d'Ivoire with Mali and Burkina Faso}

In this region, the French were again confronted with the Almami Samori Toure they had already defeated in 1894 and whom they had pushed to the East (cf. supra on Guinea border). In 1896, his "second empire" covered all northern Côte d'Ivoire from the banks of the Sassandra river (East of Odienne) to Korhogo and Bondoukou, and even extended to southern Burkina Faso and northern Ghana. ${ }^{25}$ The northern neighbors of this empire were the Kenedougou kingdom (capital Sikasso in present-day Mali), Kong and Bouna kingdoms (with eponymous capital towns in present-day Côte d'Ivoire). Under the king Tyeba (1870-1893), the Kenedougou first fought against Samori whose siege of Sikasso failed in 1887, and made an alliance with the French. After 1896, Samori rallied his successor, the king Babemba, by conceding him Tingrela (present-day Côte d'Ivoire), before it was finally taken by the French in 1898. Conversely, the Kong chiefs first allied with Samori but the latter pillaged Kong city (present-day Côte d'Ivoire) in May 1897; the Kong chiefs fled to Bobo-Dioulasso (present-day Burkina Faso). Both cities were taken by the French respectively in December 1897 and February 1898. As for the Bouna kingdom (Mosi people), formerly a vassal of the Asante Empire, it had first signed a protectorate treaty with the British in 1894, then was pillaged by Samori's son in 1896; Samori first proposed to give Bouna city to the French, but his son attacked and destroyed their military forces, so that Bouna was finally reconquered by the British in November 1897; the French finally entered Bouna in August 1898. Under French rule, the Bouna kingdom finally lost its integrity: the most important southern part, around Bouna city, was attached to the Côte d'Ivoire colony, while the northern part near Lorhoso ended in former Upper Volta (present-day Burkina Faso): the Lobi people in this latter area indeed used to pay tribute to the Bouna king. ${ }^{26}$ This most Eastern

\footnotetext{
${ }^{25}$ M'Bokolo, E., 1992. Afrique Noire, Histoire et civilisations, Du XIXè siècle à nos jours, Paris: Hatier/AUF, 2nd edition 2004, p.65

${ }^{26}$ Boutillier, J.-L., 1993. Bouna, Royaume de la savane africaine, Paris: Karthala.
} 
part of the border, near the Comoe river, is not very populated and includes national parks: the fauna reserve of Dida in Burkina Faso and the Comoe National Park in Côte d'Ivoire.

The French conquest of northern Côte d'Ivoire was achieved by the end of 1898 with the capture of Samori Toure. This conquest established a continuity between the French Soudan and the trade posts of Grand-Bassam and Assinie on the Gulf of Guinea. The territories that Samori had conquered in the Kong and Bouna kingdoms were put together in the colonial district of Kong and attached to the Côte d'Ivoire colony. For the purpose of pacification, the territories that had resisted Samori, around Sikasso (Kenedugu kingdom), Bobo-Dioulasso (Gwiriko people) and Gaoua (Lobi people), were gathered in the "Second Military Territory", also named "Volta". Its military status only ended in 1911, because these people also showed a lot of hostility to French rule. During the World War I, the same region was again the theater of large riots against military conscription (1914-16).

As a matter of fact, it is as if the conquests of Samori Toure had delineated the intra-colonial boundaries between Côte d'Ivoire on the one hand, and Soudan (Mali) and Haute-Volta (Burkina Faso) on the other hand. An official decree of 1902 only mentions a small adjustment of the most Eastern part of the border with Mali, between the Bagoe and Leraba rivers ${ }^{27}$, and another decreee of 1903 likewise very slightly modifies the North-Eastern boundary with Burkina Faso. These modifications had the objectives of putting rebel villages under martial law; apart from this peace-making territorial surgery, the layout of the border between the three French colonies remained undefined until 1947.

In 1904 the Second Military territory was attached to the French colony of "HautSenegal-Niger" that covered almost all present-day Mali, Burkina Faso and Niger, that

\footnotetext{
${ }^{27}$ Brownlie, op.cit., p.373.
} 
is about 2 millions of squared kilometers; the Niger colony was detached from this set in 1911. Last, in 1919, the World War I riots had decided the French to cut the "Haut-Sénégal" in two parts in order to increase their political control: the first part, corresponding to present-day Mali, was renamed French Soudan (Sudan) a year later (1920), and the second part, corresponding to present-day Burkina Faso, constituted the Haute-Volta colony. Between 1932 and 1946, the latter was then partitioned between former Côte d'Ivoire, French Soudan and Niger, in order to increase forced labor supply in the other three colonies, in particular for cocoa production in Côte d'Ivoire. ${ }^{28}$ All the border area that we examine was therefore annexed to Côte d'Ivoire. In 1947, HauteVolta was reconstituted in its original version; the 1919 border was never altered again afterward.

Like with Guinea, there is no detailed description of the border alignment between Côte d'Ivoire and either Mali or Burkina Faso, whether from colonial or post-colonial sources. ${ }^{29}$ According to maps, half of the alignment consists of rivers, however watercourses can be many-armed and indecisive, especially on the Malian border. For the non-river parts, no demarcation has ever taken place; no international dispute has ever been reported either.

\section{S1.4. The borders between Côte d'Ivoire neighbors}

We did no specific historical work on these latter borders and mainly rely on Brownlie (1979).

Ghana and Burkina Faso ${ }^{30}$

For its main part, the alignment of this border was fixed between 1904 and 1906;

\footnotetext{
${ }^{28}$ Massa, G., and Y. G. Madiéga (eds), 1995. La Haute-Volta coloniale, Témoignages, Recherches, Regards, Paris: Karthala, pp. 13-38.

${ }^{29}$ Brownlie, op.cit., pp.371-377.

${ }^{30}$ Brownlie, op.cit., pp.280-295
} 
it was at that time a border between British Northern Territories of the Gold Coast (making part of Gold Coast administration since 1897) and French "Soudan" (Sudan). The alignment was broadly a straight line following the 11th degree of north latitude. However, Griffiths (1986) mentions deviations on either side of the parallel to avoid villages. ${ }^{31}$ The 1904 memorandum acknowledges that the chiefs of Lan and of Kounou (Kunu) shall be compensated by respectively the British and French governments for the loss of territories caused by the passage of the frontier-line. A tiny eastern part was agreed after World War I (1919) when German Togoland was split between the British and the French mandates, as again a straight line running between two pillars, at the same time when the "Haute Volta" (Upper Volta) colony was formed.

Various sources report the boundary as demarcated during the colonial era. After independence, between 1967 and 1972, some redemarcation works were launched on the basis of the original report of the British and French commissioners of 1904.

\section{Burkina Faso and Mali ${ }^{32}$}

By a decree of March 1919 the French colony of "Haut-Sénégal et Niger" was divided and the new colony of "Haute-Volta" (Upper Volta) was constituted as a separate entity from "Soudan" (French Sudan). The only existing pieces of evidence regarding the border alignment come from the maps established under the French administration (Afrique Occidentale Française). By the end of the 1970s, the border was very little demarcated on the ground, except through some segments of watercourses. In 1974 Mali claimed that the 160 kilometers long north-eastern part was to be moved between 10 and 30 kilometers southward for ethnic purposes, i.e. Touaregs and Bellah living across the border; the position of independent Haute Volta (soon to be renamed Burkina Faso)

\footnotetext{
${ }^{31}$ Griffiths, Ieuan, 1986. "The Scramble for Africa: Inherited Political Boundaries." The Geographical Journal 2(2): 204-216.

${ }^{32}$ Brownlie, op.cit., pp.426-430
} 
was to stick to the 1922 French colonial map.

Mali and Guinea ${ }^{33}$

This border alignment is again founded on French administrative maps, here dating as early as 1911. However, in this case, a good proportion of the boundary follows rivers and stream, even if the latter can be sometimes fugitive. No dispute appears to have existed regarding this border.

${ }^{33}$ Brownlie, op.cit., pp.310-313 
Table S1.1 Initial Conditions and Early Colonial Investments: Côte d'Ivoire Borders during the Colonial Era

\begin{tabular}{|c|c|c|c|c|c|c|c|}
\hline \multirow[b]{2}{*}{ Border Side } & \multirow{2}{*}{$\frac{\text { Ghana border }}{\text { C. d'Iv. }}$} & \multicolumn{2}{|c|}{ Guinea b. } & \multicolumn{2}{|c|}{ Mali b. } & \multicolumn{2}{|c|}{ Burkina Faso b. } \\
\hline & & $\begin{array}{c}\text { C. } \\
\text { d'Iv. }\end{array}$ & Guinea & $\begin{array}{c}\text { C. } \\
\text { d'Iv. }\end{array}$ & Mali & $\begin{array}{c}\text { C. } \\
\text { d'Iv. }\end{array}$ & $\begin{array}{c}\text { Burk.- } \\
\text { F. }\end{array}$ \\
\hline Population dens. 1910 & 1.6 & 5.0 & 6.4 & 4.8 & 6.3 & 4.5 & 8.5 \\
\hline Europeans per cap. 1910 & 9.3 & 0.5 & 0.4 & 0.9 & 0.7 & 0.8 & 0.7 \\
\hline Trade tax per cap. 1912 & 0.58 & 0.02 & 0.02 & 0.01 & 0.01 & 0.07 & 0.02 \\
\hline Teachers per cap. $1910-28$ & 8.6 & 1.7 & 0.9 & 1.6 & 0.9 & 1.7 & 1.3 \\
\hline Health pers. p.c. $1910-28$ & 8.8 & 1.1 & 1.5 & 2.2 & 3.2 & 2.2 & 2.1 \\
\hline Public works $1910-28$ & 1.0 & 0.7 & 0.2 & 0.4 & 0.7 & 0.3 & 0.2 \\
\hline
\end{tabular}

Source: French colonial administration data collected by Elise Huillery (2009), hence excluding Ghana (former British).

Coverage: Administrative districts ("cercles") of the former French West Africa (Afrique Occidentale Française) located at the border of present-day Côte d'Ivoire. Ghana border: "cercles" of Assinie, Indenie and Bondoukou; Guinea border: Man (C.d'Iv. side), Beyla and Nzerekore (Guinea side); Mali border: Odienne and Kong (C. d'Iv.), Bougouni and Sikasso (Mali); Burkina Faso border: Kong and Bondoukou (C. d'Iv.), Bobodioulasso and Gaoua (Burkina Faso). In comparison with the map of figure H.1, the former colonial "cercles" were split hence the names do not correspond to present-day districts. Notes: Population dens. = enumerated residents per squared kilometers; Europeans = enumerated Europeans per 1,000 people; Trade tax $=$ trade tax revenue per capita in 1910 French Francs; Teachers $=$ number of teachers per 100,000 people; Health pers. = Health personnel per 100,000 people; Public works $=$ Public works (infrastructures) expenditures per squared kilometers in 1910 French Francs. 


\section{S2. The construction of variables for analysis}

\section{S2.1. Consumption}

The consumption variable is the sum of four distinct components: 1 . Consumption of own food production; 2. Food expenditures including meals outside the household; 3. Housing expenditures: rents paid and imputed rents; home cleaning and reparation; water, electricity and other fuels; 4. Other current expenditures, including education. Consumption of own production other than food is disregarded. Gifts received in kind are not included for they were not collected in all countries. Gifts and transfers to other households are disregarded, as well as tax payments. Expenditures for ceremonies and for health were not included for being too infrequent. For the same reason, durable goods acquisition and reparation are not included (furniture, domestic appliances, radio and TV sets, vehicles).

No correction was considered for within countries regional price levels differences (this kind of information is only available for the early surveys in Côte d'Ivoire and Ghana). Monthly data on national consumer price index (CPI) was used to express all components in a common base-year (1988 or 1993), taking into account their specific recall period and the month and year of recording. Although very much imperfect as CPI are not disaggregated by products, this correction is however better than nothing for periods of high inflation: in Ghana whatever the date, in Burkina Faso and Mali just after the CFA franc devaluation in $1994 .{ }^{34}$ Household consumption levels are then translated in current dollars at base year exchange rates and prices $(1988,1993)$, using

\footnotetext{
${ }^{34}$ For Mali 1994 the correction is even cruder, as the survey only covered four months (March to June), and the precise month of consumption recording has not been kept in the datafiles: we simply do as if the survey had been implemented in April 1994, we assume that all recorded food expenditures were made then, and that non-food expenditures, whose recall period is the year, were uniformly distributed along the May 1993-April 1994 period. Alternatively, as mentioned in the text, we make no correction for inflation, this providing an upper bound.
} 
either official or parallel (in the cases of Ghana before 1989 and Guinea) exchange rates.

Regarding consumption of own food production, all surveys directly ask households about the market value for each product, with a recall period that may vary from one survey to another. In GLSS3-4 (Ghana 1992 and 1998) and EIBC (Guinea), quantities consumed are also recorded: in that case, within PSUs median unit prices can be computed and a second market value constructed. Market values are then translated into monthly consumption (with a multiplier depending on the recall period) and divided by the corresponding monthly CPI, then turned into annual consumption using declarations about how often the product is consumed during the year (when available). They are finally summed across products. When two measurements have been constructed (cases of GLSS3-4 and EIBC), we check they are fairly correlated (minimum correlation coefficient of 0.5), and we take the average of the two. ${ }^{35}$

Regarding food expenditures, the procedure is nearly the same, except that quantities are not collected. All surveys record food expenditures during the last 15 days or the last month. This allows to construct a first simple measurement of food expenditures: (i) translation into a monthly basis (double the value when the recall period is 15 days), (ii) division by monthly CPI, (iii) multiplication by 12 to obtain the annual expenditures estimate. The Côte d'Ivoire (CILSS and ENV) surveys and the early Ghana surveys (GLSS1-2) additionally record how many months each product has been consumed during the year. This allows to construct a second measurement where the last step is replaced by (iii) multiplication by number of months of consumption to obtain the annual expenditures estimate. In the CILSS and GLSS1-2 this number of months is matched with a second declaration of expenditures over a recall period of one year (rather than one month). Here again, we keep the average of the two measurements after having checked their correlation.

\footnotetext{
${ }^{35}$ Note that the EMCES (Mali 1994) survey does not collect any information on consumption of own production.
} 
Regarding housing expenditures, information usually comes from specific survey modules, and is collected over or twelve months recall period. Combined with monthly or yearly CPIs, we then straightforwardly obtain an annual aggregate at base-year prices. For house-owners or households with free accommodation, the imputed rent is the predicted value derived from a regression estimated on tenants. The regression relates the rent paid to the characteristics of the house only; one such regression is estimated for each survey, no correction for selection is made. We check that the resulting housing budget shares are sensible.

Last, for all other expenditures, the longest recall period (usually 12 months) has been preferred when two recall periods are available. Exceptions are hygiene, cigarettes and fuels. Information on education expenditures (including transportation and sometimes food) are usually derived from a specific module.

The food consumption aggregate is trimmed separately by dropping observations for which the logarithm is under or above the mean by 5 standard deviations. Households declaring no food consumption are directly withdrawn. This "clean" food consumption amount is then summed with other expenditures and the total consumption amount is trimmed again with the same \pm 5 standard deviations rule. In the end, in all surveys, less than $1 \%$ of households are withdrawn from the sample by this trimming procedure.

\section{S2.2. Geographical variables}

We obtain the geographical coordinates of survey clusters from combining NGA GEOnet Names Server, Falling Rain Global Gazetteer and regional maps. These coordinates are then used to construct the geographical attributes of clusters: altitude, rainfall, distance to the nearest river and distance to national borders.

NGA GEOnet Names Server: http://earth-info.nga.mil/gns/html Falling Rain Global Gazetteer: http://www.fallingrain.com/world 


\section{Altitude}

Elevation data are from the NASA Shuttle Radar Topography Mission (SRTM). The data used is from the Global Coverage 3 Arc Second database, available from the USGS EROS Data Center. The basic hgt files are first converted to Arc Grid Ascii format using the gdal_translate utility, and then to Stata format using the ras2dta program. ${ }^{36}$ The resolution of the original elevation files is then reduced by averaging altitudes over square blocks of 25 pixels. The coordinates of survey clusters are finally matched to those of these squares.

USGS EROS Data Center: http://edc.usgs.gov/products/elevation.html gdal_translate utility: http://www.gdal.org/gdal_translate.html

\section{Rainfall}

Rainfall data are from the NASA Global Precipitation Climatology Project (GPCP). We use the data for the years 1984-2001. The original monthly data are averaged over each year, and further averaged over the 1984-2001 period for the calculations in the paper.

NASA GPCP: http://precip.gsfc.nasa.gov.

\section{Distance to the nearest river}

Hydrographic data are from the NASA Hydro 1K Africa database. For each survey cluster, the distance to the nearest stream within the same drainage basin is computed using the Distance Calculator utility of Mapinfo software.

NASA Hydro 1K Africa database:

http://eros.usgs.gov/products/elevation/gtopo30/hydro/africa.html

\footnotetext{
${ }^{36}$ Müller, D., 2005. "Stata in space: Econometric analysis of spatially explicit raster data", The Stata Journal, 5: 224-238.
} 


\section{Population density}

Data for estimated population density in 1990 are from the Gridded Population of the World (GPW) database.

SEDAC: http://sedac.ciesin.columbia.edu/

\section{Distance to cities}

The Africapolis database, designed by French geographers (SEDET, CNRS and University Paris-7), is probably the most complete to date. It provides the geographical location of West African cities as well as population estimates for the years 1960 to 2000.

http://www.e-geopolis.eu

\section{Distance to border}

Digital data maps for all the countries come from the USGS Africa Data Dissemination Service. Distance to the national borders is computed using the Distance Calculator utility of Mapinfo software.

USGS: http://earlywarning.usgs.gov/adds

\section{Border districts}

Figure S2.1 thereafter provides a map giving the location of administrative districts located in the border areas (for more details, see historical appendix). The Ghanaian region of Brong-Ahafo extends far from the border with Côte d'Ivoire, but in total only one quarter of Ghanaian survey clusters are more than $100 \mathrm{~km}$ away from the border, the mean distance being $77 \mathrm{~km}$ (GLSS1-2 and GLSS4). 


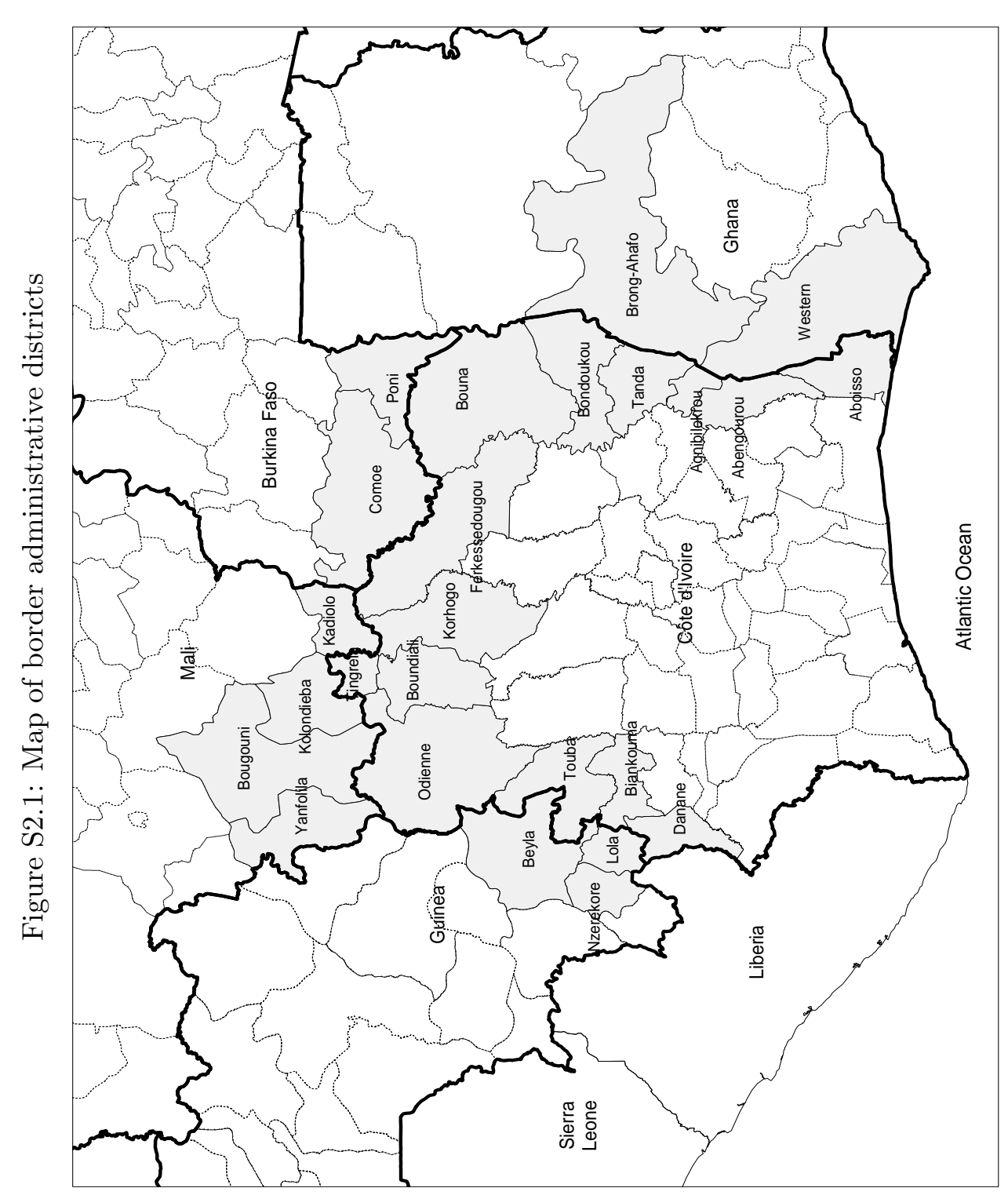




\section{S3. Additional results at other borders}

As alluded to in the main text, in previous versions of this work we also looked at the border of Côte d'Ivoire with Burkina Faso. However identification had drawbacks. The western half of this border follows the Leraba and the Comoé rivers, and a few discontinuities in elevation and distance to river are detected. The main difficulty actually comes from the distribution of localities along the boundary. The middle part of this border is not very populated and hardly represented in the sample, as the Côte d'Ivoire side lies just above a large national park; further, most Ivorian localities are urban or peri-urban, lying around the large cities of Bouna (East) or Ferkéssédougou (West). Finally and most importantly, the difference in urban structure accounts for all the border discontinuities in consumption per capita or children stunting that can be identified in the first place. It is hard to know whether this feature reflects a small sample effect or a real world pattern.

We also looked at BDs between neighbors of Côte d'Ivoire that happen to be adjacent, this making a set of six additional country-period pairs: Guinea/Mali in 1994, Burkina Faso/Mali in 1994 and 1998-2001, and Burkina Faso/Ghana in 1998, and even 1992 and 2003 using DHS data. The striking result is that we could not find any significant and robust $\mathrm{BD}$, with one exception only: Ghanaian households seem to benefit from an increased access to electricity at the border with Burkina Faso in 2003. These results suggest that large border discontinuities are much less likely to emerge when countries display similar levels of wealth. Macroeconomic figures indeed show that it is only in the second half of the 2000s that Ghana started to overtake the three other countries, and to catch up with Côte d'Ivoire (Eberhardt and Teal 2010). Meanwhile, Burkina Faso and Mali were staying more or less at par, and Guinea had fallen down to their level. 